\title{
Conviction Statistics as an Indicator of Crime Trends in Europe from 1990 to 2006
}

\section{Marcelo F. Aebi \& Antonia Linde}

\section{European Journal on Criminal Policy} and Research

\section{ISSN 0928-1371}

Volume 18

Number 1

Eur J Crim Policy Res (2012) 18:103-144 DOI 10.1007/s10610-011-9166-7

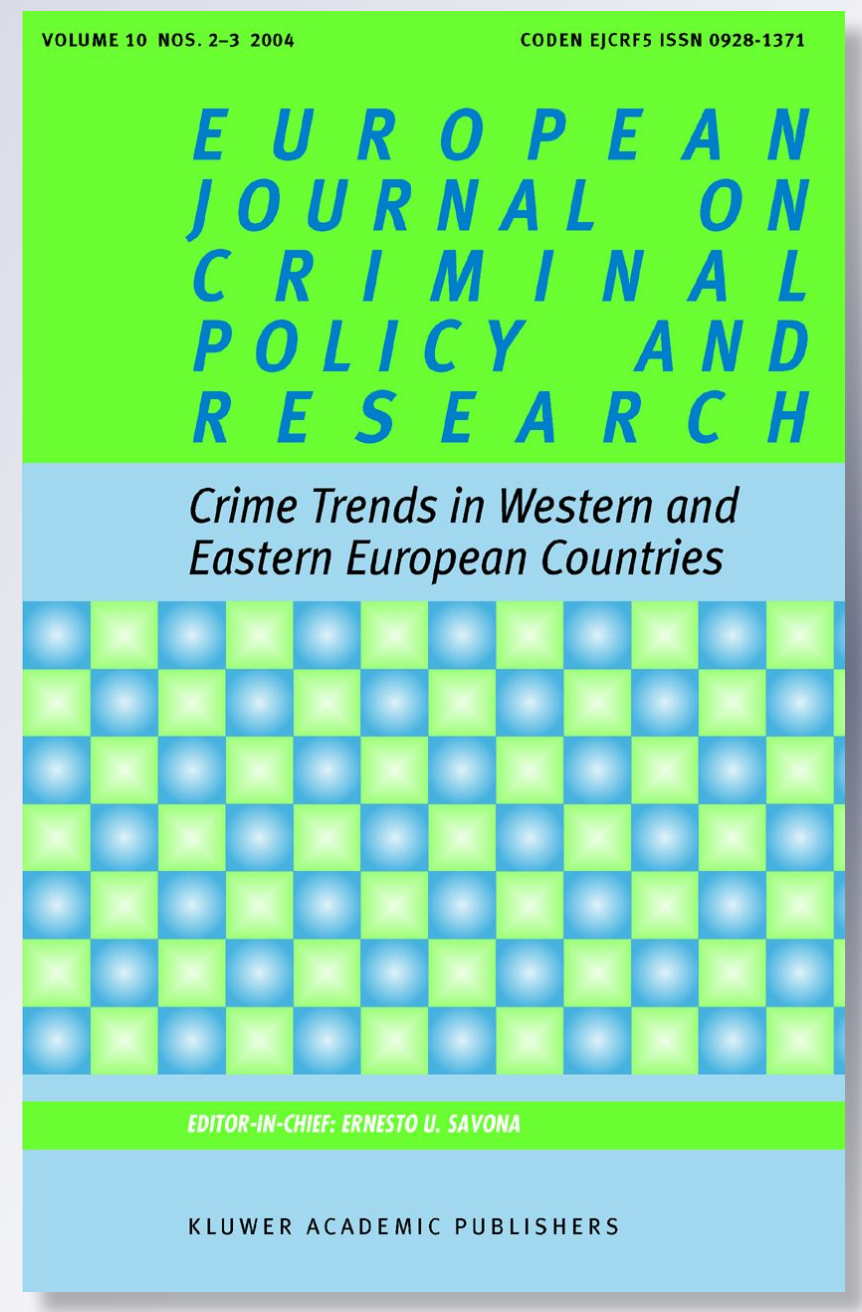

E U R O P E A N J OURNAL ON $C R / M I N A L$ POLICY AND RESEARCH

Crime Trends in Western and Eastern European Countries

Springer 
Your article is protected by copyright and all rights are held exclusively by Springer Science+Business Media B.V.. This e-offprint is for personal use only and shall not be selfarchived in electronic repositories. If you wish to self-archive your work, please use the accepted author's version for posting to your own website or your institution's repository. You may further deposit the accepted author's version on a funder's repository at a funder's request, provided it is not made publicly available until 12 months after publication. 


\title{
Conviction Statistics as an Indicator of Crime Trends in Europe from 1990 to 2006
}

\author{
Marcelo F. Aebi • Antonia Linde
}

Published online: 24 December 2011

(C) Springer Science+Business Media B.V. 2011

\begin{abstract}
Convictions statistics were the first criminal statistics available in Europe during the nineteenth century. Their main weaknesses as crime measures and for comparative purposes were identified by Alphonse de Candolle in the 1830s. Currently, they are seldom used by comparative criminologists, although they provide a less valid but more reliable measure of crime and formal social control than police statistics. This article uses conviction statistics, compiled from the four editions of the European Sourcebook of Crime and Criminal Justice Statistics, to study the evolution of persons convicted in European countries from 1990 to 2006. Trends in persons convicted for six offences -intentional homicide, assault, rape, robbery, theft, and drug offences- and up to 26 European countries are analysed. These trends are established for the whole of Europe as well as for a cluster of Western European countries and a cluster of Central and Eastern European countries. The analyses show similarities between both regions of Europe at the beginning and at the end of the period under study. After a general increase of the rate of persons convicted in the early 1990s in the whole of Europe, trends followed different directions in Western and in Central and Eastern Europe. However, during the 2000s, it can be observed, throughout Europe, a certain stability of the rates of persons convicted for intentional homicides, accompanied by a general decrease of the rate of persons convicted for property offences, and an increase of the rate of those convicted for drug offences. The latter goes together with an increase of the rate of persons convicted for non lethal violent offences, which only reached some stability at the end of the time series. These trends show that there is no
\end{abstract}

M. F. Aebi $(\bowtie) \cdot$ A. Linde

School of Criminal Sciences, Institute of Criminology and Criminal Law, University of Lausanne, ESC-ICDP-Sorge-BCH, CH-1015 Lausanne, Switzerland e-mail: Marcelo.Aebi@unil.ch

A. Linde

e-mail: alindeg@uoc.edu

\section{A. Linde}

Department of Law and Political Science, Universitat Oberta de Catalunya (Open University of Catalonia), Avinguda Tibidabo, 39-43, 08035 Barcelona, Spain e-mail: Antonia.Linde@unil.ch 
general crime drop in Europe. After a discussion of possible theoretical explanations, a multifactor model, inspired by opportunity-based theories, is proposed to explain the trends observed.

Keywords Alphonse de Candolle - Central and Eastern Europe - Convicted persons · Conviction statistics · Crime drop · Crime trends · European Sourcebook · Internet · Routine activities approach · Western Europe

\section{Introduction}

This article analyses the evolution of convicted offenders for six different offences in up to 26 European countries, from 1990 to 2006 . The first part of the article discusses the value of conviction statistics as a measure of crime and formal social control, paying special attention to the historical development of such statistics and the debate about their validity and reliability over two centuries. This is followed by a methodological section that presents the data from the European Sourcebook of Crime and Criminal Justice Statistics used for the analyses, together with the validity checks and statistical procedures applied to improve their quality. The results of the analyses are shown in the third section, which presents and describes trends for each offence in the whole continent as well as in Western Europe and in Central and Eastern Europe. Finally, the discussion section reviews the different theoretical explanations that could be proposed to explain such trends and the current debate about the so-called crime drop in industrialized countries. It also proposes an explanation of crime trends based on a multifactor model that draws on opportunity-based theories and takes into account the political, economical and social changes observed in Europe during the last two decades.

\section{Conviction Statistics as a Measure of Crime and Formal Social Reaction}

\section{Historical Development of Conviction Statistics}

Conviction statistics, also known as court statistics and judiciary statistics, were the first official statistics -i.e. statistics produced by the State- on crime available in Europe. Sweden had vital statistics -i.e. statistics on the causes of death- on the number of victims of homicide since the 1750s, and the same is true for Finland, which was a part of Sweden until 1809 (von Hofer 1990). Figures of committals for indictable crime -which correspond to persons charged for felonies and for misdemeanours tried by a jury (Hastings 2001)started to be published annually in England and Wales in 1810, with data going back to 1805 (Emsley 2005: 22). ${ }^{1}$ But the first comprehensive national criminal statistics were introduced in France in 1825. They were followed by the ones published in Denmark in 1828 and in Sweden in 1836, and all these statistics were based on court data.

The French statistics -published in 1827 with data from 1825- were called the Compte général de l'administration de la justice criminelle en France. They were "divided into four parts: the first included all prosecutions in the assize courts; the second, the verdicts of correctional tribunals; the third, the verdicts of the tribunals of the police courts; and the fourth,

\footnotetext{
${ }^{1}$ In contemporary terms, they can be seen as a sort of prosecution statistics that cover the cases brought before a court for some types of offences only.
} 
statistical information about the criminal process from other jurisdictions such as the royal courts. For each département, the Compte measured the annual number of known and prosecuted crimes against persons and property, whether the accused (if prosecuted) were acquitted or convicted, as well as the punishment accorded [to] the latter" (Beirne 1993: 74).

According to Christiansen and Gram Jensen (1972), official criminal statistics in Denmark date back to 1828 , and the first four annual surveys were published in a governmental periodical. They were called sanction statistics and were based on the number of convictions and other sanctions, and not on the number of persons convicted. However, the first 12 years of these statistics were not reliable; as a consequence, trends can only be established since 1841 (Christiansen and Gram Jensen 1972).

In Sweden, since 1836, the national statistics included statistics on crimes (Lindström 2008). These statistics were based on court sentences and other findings of guilt, such as summary fines and waivers of prosecution (von Hofer 2000b, 2003).

The statistical series published in England and Wales since 1810 were partial -they did not cover non-indictable offences, which can be tried without a jury (Hastings 2001)- and considered by the local researchers as inaccurate and clearly less sophisticated than the French ones, which were seen as model in the field (Emsley 2005: 22-23). It is only in 1857 that England and Wales started publishing comprehensive national criminal statistics, which combined court and police data (Maguire 2007: 244). They "consisted of, first, indictable offences reported to the police that had not necessarily resulted in an arrest or been 'solved'; second, committals for trial, both on indictment and before summary jurisdiction; and third, the number of persons convicted and imprisoned" (Emsley 2005: 23).

These observations on the birth of criminal statistics allow us to place the first debates about their validity in their historical context, and to read such debates keeping in mind that they referred systematically to conviction statistics. It is only during the second half of the twentieth century that police statistics -and World Health Organization data on deaths due to homicide and intentional injury (WHO health statistics)- became the main measure used by criminologists interested in comparative research. The key reason for that choice could seem merely empirical: Interpol started publishing data on offences recorded by police forces across the world in 1954 (Stamatel 2006) -a collection that was unfortunately discontinued by a resolution of Interpol's General Assembly in $2006^{2}-$, creating thus a major database for comparative criminologists. However, the development of the Interpol data collection was, at least partially, one of the practical results of a former theoretical discussion on the validity of criminal statistics.

In fact, immediately after the publication of the French national judiciary statistics, their validity was questioned by de Candolle (1830/1987a). According to Beirne (1993: 105), de Candolle was probably the first author that mentioned the problem of the dark figure of crime. Indeed, de Candolle (1830/1987a) unveiled most of the problems related to the use of conviction statistics as measures of crime. ${ }^{3}$ In particular, he enumerated the different

\footnotetext{
${ }^{2}$ See http://www.interpol.int/public/ICPO/GeneralAssembly/AGN75/resolutions/AGN75RES19.asp. In the context of this article, it is interesting to point out that the section Frequently Asked Questions of Interpol's website specifies that "The decision to remove the statistics was taken as some users and some members of the media were making comparisons between countries based on these statistics, when different collection methods make such comparisons problematic" (http://www.interpol.int/FAQs, last accessed on 23-09-2011). ${ }^{3}$ The contribution of Alphonse de Candole (1806-1893) to the debate on the validity of official statistics was seldom taken into account by criminologists until he was rediscovered by Bomio and Robert (1987) in the 1980s. For example, in his seminal article on the basis of a crime index, Sellin (1931) summarizes the positions of Georg von Mayr, Gabriel Tarde, and V. Verkko, but does not mention de Candolle. Nor is he mentioned in the influential works of Robinson $(1910,1911)$ about the history and organization of criminal statistics in the United States of America.
} 
causes of the dark figure of crime -including the offenses not discovered by their victims, the offences for which the author is unknown, the decision by the victim of not reporting the offence, and the cases in which the legal procedure does not lead to a sentence of a court- as well as the influence of the prosecution activity on sudden changes in crime trends. He also warned about cross-national comparisons because the number of unknown crimes varied from one country to another (de Candolle, 1830/1987a). One year later, the publication of Recherches sur le penchant au crime, aux différents âges par Quételet (1831) led de Candolle (1832/1987b) to publish a second text in which he tackled the idea of a constant proportion between the total number of offences committed and the number of offences known and tried by a judicial authority, which had been proposed by Quételet. In the same article, de Candolle (1832/1987b) insisted once more on the almost impossibility of performing cross-national comparisons. In particular, he explained that, if such comparisons were to be made, they should be based on the number of accused persons instead of on the number of sentenced persons. The reason was that many offences known to the prosecution authorities do not lead to a conviction. This is, indeed, the same reasoning behind the so-called Sellin's dictum (Coleman and Moynihan 1996: 10), which stated, one hundred years after de Candolle, that "the value of a crime rate for index purposes decreases as the distance from the crime itself in terms of procedure increases" (Sellin 1931: 346, emphasis in the original). More than 35 years later, this idea was presented in a graphic way by the President's Commission on Law Enforcement and Administration of Justice (1967: 8-9), which represented the criminal justice system as a funnel in which the number of cases decreases -because some cases are removed as they are, for example, unknown to the police or because the police, the prosecutors or the courts cannot solve them- as the process advances. ${ }^{4}$

In order to understand the position of Sellin (1931), one must place it in its historical and geographical context, which corresponds to the period in which the Uniform Crime Reporting system (UCR) was created in the United States. One of the main decisions that had to be taken at that moment was whether to use court or police data as a basis for the UCR, which was meant to be the first comprehensive collection of criminal data at the national level. Police statistics had developed during the second half of the nineteenth century and criminologists like von Mayr -who, according to Sellin and Wolfgang (1964: 14), was the first one to use crimes known to the police to study criminality in Bavaria, Germany, in a study published in 1867- considered that they should be the main source for research on moral statistics (Robinson 1910). Simultaneously, Robinson $(1910,1911)$ had traced the history of criminal statistics in the United States -in which many states were producing their own statistical collections, but only prison statistics were collected at the national level- and presented a plan for their reorganization. This plan was inspired by the criminal statistics available in European countries and was based on the development of judicial statistics with two correlated counting units: "the criminal" and "the crime", i.e. persons convicted and offences for which these persons were convicted. Indeed, Robinson $(1910,1911)$ seldom paid attention to police data and concentrated on the advantages of judicial statistics over prison statistics. At the beginning of the twentieth century, his position was shared by the American Institute of Criminal Law and Criminology (Koren 1910). Nevertheless, time went by and, even if

\footnotetext{
${ }^{4}$ While a funnel or an iceberg provide a useful graphic representation of the shape of the criminal justice system, the image of a sieve with different sized meshes allows an illustration of the way in which the system works (Killias et al. 2012: 342). The meshes filter out some of the cases, while a funnel would let them all pass through.
} 
Robinson (1920) went as far as suggesting the practical way in which judicial statistics could be collected, ${ }^{5}$ the efforts to create a nationwide collection of criminal statistics continued to be unsuccessful. Moreover, the debate about the type of statistics that should be collected was heading into a different direction as the one proposed by Robinson and other statisticians.

According to Maltz (1977: 35), "By the late 1920s it was generally agreed that the crime collected by the police would be the most accurate for statistical purposes". In that context, Robinson (1928) published an article in which he expressed his hope that "something good for criminal statistics" could come out of the public discontent with the criminal justice system (Robinson 1928: 125). He did not take position about the type of criminal statistics to collect, but he expressed his worries about the fact that some states were collecting data through their bureau of criminal identification: "A bureau of criminal identification belongs within the police organization and the collection and interpretation of criminal statistics should be entirely free from the influences of any branch of the administration of criminal justice" (Robinson 1928: 127). At the same time, Vollmer (quoted by Maltz 1977: 34) considered, that "the only dependable data upon which safe conclusions may be based are the actual number and kind of complaints received by law enforcement officials". August Vollmer was at that time chief of police of Berkeley, California, and president of the International Association of Chiefs of Police (IACP), and he was concerned about the view offered by the press of crime trends, which suggested that the United States were undergoing a crime wave (Maltz 1977; Rosen 1995). The IACP committee on Uniform Crime Records published in 1929 a very influential report (IACP, 1929) that -combined with the efforts of the Laura Spelman Rockefeller Memorial (LSRM) and the Social Science Research Council (SSRC) to promote a police-based crime data system (Rosen 1995)- led the Congress of the United States, one year later, to charge the Federal Bureau of Investigation (FBI) to start collecting data for the UCR. Thus, in 1930, the national police statistics of the United States were born.

Sellin (1931) published his article immediately after that, taking position in the debate about the validity of police and conviction statistics, and suggesting indirectly the way in which the future crime index elaborated on the basis of the data collected for the URC -that he mentions in page 346 , note 22 - could be elaborated. This can be clearly seen in the sentence that Sellin (1931) wrote immediately after the one that was going to become his dictum: "In other words, police statistics, particularly those of 'crimes known to the police' are most likely to furnish a good basis for a crime index". That sentence is accompanied by a footnote stating that he was "in complete disagreement" with the Report of the Commission for the comparative study of criminal statistics of various countries, presented in the 18th session of the International Institute of Statistics -held in Warsaw, in 1930-, which concluded that "for the purpose of determining the status and the movement of criminality in each country, it is the statistics of crimes objectively determined by irrevocable and definitive sentences which should be submitted to study" (Sellin 1931: 346).

Taking into account the enormous international influence of research in criminology conducted in the United States since the 1930s, it is not exaggerated to say that the decision of the Congress to use police data for the UCR closed the scientific debate on the

\footnotetext{
5 "I maintain that before the records of our criminal courts are filed away in the burying grounds of the Clerks of Quarter Sessions or similar officials, there should be something in the nature of a face-sheet attached either to the bill of indictment or to the record of the procedure before the court as a basis for criminal statistics" (Robinson 1920: 161).
} 
comparative validity of conviction and police statistics. ${ }^{6}$ The UCR became for at least two decades - until the development of self-reported delinquency studies- the major source of empirical data for research, and criminologists across the world turned also to their national police statistics to conduct similar studies. Conviction statistics were reduced to a secondary role that became still less important, at the international scale, when Interpol started its collection of criminal statistics in 1954. Even the development of the United Nations Surveys on Crime Trends and the Operations of Criminal Justice Systems, UNCTS (UNODC 2010) in the second half of the 1970s -which included data on police and on conviction statistics since 1970-, did not change that situation. Nowadays, cross-national comparisons of crime levels and crime trends continue to be based mainly on police statistics and WHO health statistics. In that context, one of the goals of this article is to test -through a comparison of the trends in conviction statistics with the ones observed in police and victimization statistics (Aebi and Linde 2010)- whether conviction statistics provide an appropriate measure of crime trends at the European level.

\section{Validity and Reliability of Conviction Statistics}

In the previous chapter, we presented some of the criticisms that de Candolle (1830/1987a, $1832 / 1987 b$ ) addressed to the first judiciary statistics. Almost two hundred years later, his criticisms are still relevant and they continue to affect the validity of conviction statistics. Apart from the problems already mentioned, in his analysis of the problems involved in cross-national comparisons of those statistics, de Candolle (1832/1987b) highlighted the influence of the particularities of each national criminal justice system. In that context, he paid particular attention to the presence or the absence of a jury, which he considered the main cause of mistakes in the comparisons. He also identified legal definitions of offences and the procedural system of each country as major sources of distortions of the comparisons. At the beginning of the twentieth century these issues continued to be a matter of discussion. Thus, Robinson (1912), pointed out that "some states [of the United States of America] count double infractions of a particular species as separate crimes while other consider them as one", and that "where codes do not consider the continuity of a crime it depends on the judge whether such acts shall be considered as one infraction or two" (Robinson 1912: 246). Current research also continues to pay attention to these factors, stressing the fact that the statistical counting rules applied by each country to establish its national conviction statistics render cross-national comparisons almost impossible. Thus, the metadata included in the 4th edition of the European Sourcebook of Crime and Criminal Justice Statistics (Aebi et al. 2010: 165-6) shows that the majority of the European countries apply a principal offence rule, which implies that an offender

\footnotetext{
${ }^{6}$ August Vollmer (1876-1955) later became a university professor, and the American Society of Criminology paid tribute to his memory by naming one of its Awards after him. Thorsten Sellin (1896-1994) deserved the same honour, and his dictum of 1931 is almost systematically quoted when discussing the validity of crime measures. Louis N. Robinson updated in 1933 his history of criminal statistics in the United States, dedicating a chapter to the Association of Chiefs of Police and the decision of the Congress on the UCR. In a major example of fair play in scientific research, Robinson declared: "The author has only the highest praise to bestow upon the research performed by the Committee of the International Association of Chiefs of Police" (Robinson 1933: 134). He also acknowledged that "Several very practical reasons led to the decision to place the work in the Bureau of Investigation and it is very doubtful if the system could have been started in any other way" (Robinson 1933: 134). It is extremely difficult to find biographical information about Robinson. The Library of Congress Online Catalogue mentions that he was born in 1880, but provides no information on the year of this death (http://catalog.loc.gov/, last accessed on 23-09-2011).
} 
convicted for several offences will be shown only once -for the most serious offence- in conviction statistics. However, it is not completely clear whether countries determined the seriousness of the offence on the basis of its nature, the punishment imposed or the maximum applicable sentence. There are also differences regarding the point at which data is collected for the statistics because some countries record court decisions before any appeal and others record them after the appeals have been exhausted (Aebi et al. 2010: 165-6).

Those and similar related problems affect the validity of conviction statistics not only when they are used at the macro-level -e.g. for comparisons across countries-, but also when they are used as a measure of crime at the individual level. Thus, in the framework of the Swiss Heroin Prescription Programs (Ribeaud et al. 2004), a comparison of selfreported delinquency surveys, victimization surveys, police files and court files for a sample of drug-addicts, showed that conviction data can be problematic when trying to establish the frequency of continuous offences - such as drug consumption and drug dealing-, because the whole series of acts is included under only one conviction (Aebi 2006: 260). They are also problematic when trying to establish the criminal career of an offender because a criminal conviction is the last resource for a juvenile court and also because only the most serious offences lead to a criminal conviction. As a consequence, the first conviction of an offender will not necessarily reflect his or her first offence. In the same perspective, when several offences are included in the same sentence, it is almost impossible -without consulting the original files- to establish their temporary order. Moreover, in countries with a civil law legal system, conviction data are based on the articles included in the Criminal Code, which sometimes do not allow a detailed criminological classification of the acts committed. For example, theft can include pickpocketing, shoplifting and other forms of theft that are committed with completely different modus operandi. (Aebi 2006: 260). These problems exist when the counting unit of conviction statistics is the conviction itself and also when the counting unit is the person convicted, but they are more pronounced in the second case. Indeed, conviction statistics based on the number of persons convicted represent a measure of the prevalence of delinquency -the number of persons convicted could also be expressed as the percentage of the population that has been convicted- that does not seem appropriate to measure the frequency or incidence of delinquency -i.e. the number of offences that led to a conviction. For example, an increase in the number of persons convicted may be the consequence of an increase in the number of offences committed in group, even if the total number of offences remains stable. ${ }^{7}$

In sum, if the validity of a crime measure is defined as its capacity to measure efficiently the phenomenon under study -i.e. criminality-, one can say that conviction statistics are less valid than police statistics. As we have seen, this was the main message of Sellin (1931), although the language of research has evolved and the concept of value, used by him, has been replaced by the concept of validity, and it has been complemented with the concept of reliability. Police statistics are more valid than conviction statistics because they are closer to the offence itself. They are influenced mainly by the propensity of the population to report offences, the way in which those offences are recorded, and the criminal policy priorities as well as the efficiency of police forces. Conviction statistics

\footnotetext{
7 The problems related to the counting unit used in criminal statistics were already discussed in the nineteenth century by Georg von Mayr (Robinson 1910). Robinson (1910) also provided a discussion on the advantages and disadvantages of the three main units used in criminal statistics (the affair or case, the infraction of the law, and the delinquent).
} 
intervene at a later stage of the procedure and therefore are influenced not only by all those factors but also by the intervention of the Public Prosecution Services, which filters the suspects that arrive at the trial stage. Thus, they include fewer offences than police statistics, and many of these offences have disappeared because of lack of evidence. For example, analysing rape offences in Sweden, von Hofer (2000a) has shown that, in 1997, the police had recorded 1,708 offences but had completed the investigation of only 1,434 . Thus, there was a drop of $16 \%$ between the offences known to the police (input) and the offences forwarded to the prosecution authorities (output). Among the 274 cases that disappeared during the police investigation, there were 42 in which the reported offence did not constitute a rape and 179 cases in which it was not possible to establish the presence of a criminal conduct (von Hofer 2000a). ${ }^{8}$ The subsequent intervention of the prosecution services reduces even more the number of cases brought before a court because of lack of evidence or lack of public interest in prosecution. Thus, a comparative study of the role of the Public Prosecution Services in Europe has shown that, roughly, between $40 \%$ and $50 \%$ of the cases treated by five of those Services -France, Germany, Netherlands, Poland and Sweden- in 2004 ended in a simple drop or in a drop based on the grounds that there was no public interest in prosecution (Jehle et al. 2008).

In contrast, if the reliability of a crime measure is defined as its capacity to provide measures that are inter-subjective and reproducible -i.e. to provide the same measure independently of the person that manipulates the instrument-, one can say that conviction statistics are more reliable than police statistics. The reason is that conviction statistics are based on a decision taken by a judge that disposes of more detailed information than the police officers who registered the offence. For example, for the police officers that discover a person killed with a firearm, it is almost impossible to establish the intention of the author of the lethal shot (did he/she want to kill the person or to wound her? Was it an accident?). ${ }^{9}$ On the contrary, the judge has collected all the relevant information and can pronounce an informed decision. At the same time, judges are obliged to take their decisions according to the Criminal Code (in countries with a civil law system) or according to previous jurisprudence (in countries with a common law system). Thus, disposing of the same information, different judges should arrive at the same decision. Moreover, if their decisions are dissimilar, a superior court will unify the jurisprudence (Killias et al. 2012: 41-42).

As a consequence, we can conclude that conviction statistics are less valid but more reliable than police statistics as measures of crime. Conversely, as crime measures, police statistics are more valid but less reliable than conviction statistics.

Nevertheless, those considerations about reliability and validity concern mainly the use of conviction statistics as measures of the level of crime and the formal social control. In this article, on the contrary, conviction statistics will be used to measure crime trends. In that context, it can be accepted that official statistics offer a reasonably valid basis to study time series provided that the reporting and recording practices, as well as the legal definitions of offences, have not experienced substantial changes during the period

\footnotetext{
${ }^{8}$ In the same perspective, a study of the role of police forces in the criminal justice proceedings has shown that, as far as minor offences are concerned, the police forces of several European countries can decide to drop cases because of insufficient evidence or because the offender is unknown (Elsner, Smit \& Zila, 2008). Such interventions by the police reduce the number of cases that are treated by the Public Prosecution Services and, later, by the courts.

${ }^{9}$ See, for example, Ferracuti et al. (1962), who conducted an empirical study that highlighted many of the mistakes in the identification and classification of crimes by police officers.
} 
considered, or whenever the influence of such changes can be measured by the researcher (CoE 1999: 13; von Hofer 2000a).

Summarizing the criminological controversies on the pertinence of conviction statistics as measures of crime, von Hofer (2000b, 2003) concludes that there are two opposite views among researchers. The first one considers conviction statistics as an indicator of formal social control -reflecting the exercise of State control through criminal law-, which are useless as indicators of the true volume of offences and offenders. The second one considers that they can describe basic trends in offending even if the slopes of increases and decreases are not perfectly depicted. "This view of court statistics is primarily founded on the idea that, in a constitutional state, court sentences do in fact reflect the guilt of the accused. The State deploys a highly bureaucratic process to establish the guilt of the accused person, and the parties finally recorded in court statistics do not find their way there on an arbitrary basis. In most cases, there is a valid connection between the offence and the sentence. Thus, to some extent, court statistics do mirror offending behaviour, even if its true volume generally is greatly under-estimated" (von Hofer 2003: 163). The same author concludes that this is an empirical problem which cannot be solved through theoretical analysis and statements. As a consequence, he combines both approaches while using conviction statistics to study crime trends in Sweden (von Hofer 2000b, 2003). The same logic is applied in this article.

\section{Data and Methods}

The analyses included in this article are based on the data on conviction statistics included in the four editions of the European Sourcebook of Crime and Criminal Justice Statistics (hereafter European Sourcebook) that cover the years 1990 to 2007 (CoE 1999; Killias et al. 2003; Aebi et al. 2006, 2010). ${ }^{10}$ However, almost half of the 26 countries studied in this article were unable to provide data on persons convicted for 2007. For that reason the series studied cover the period 1990 to 2006. Bearing in mind the problems mentioned in the previous section, a series of validity checks were performed on that data in order to control the influence of changes in legal definitions and data recording practices, as well as the consistency of the time series obtained. In the following chapters we will present such checks and describe the logic used to include or exclude offences and countries from our analyses, as well as the interpolation, extrapolation and weighting procedures applied to the data.

\section{Offences Included}

This article covers trends in persons convicted for six offences. We have excluded the offences that were not included in all the editions of the European Sourcebook (e.g. fraud, computer offences, money laundering) as well as those for which data were available for less than ten countries (theft of motor vehicle, burglary, domestic burglary, and drug trafficking). Thus, the offences included in our analyses are the following: intentional homicide -total and completed (i.e. including and excluding attempts)-, assault, rape, robbery, theft, and drug offences.

\footnotetext{
$\overline{10}$ The raw data tables available on the European Sourcebook website (www.europeansourcebook.org) were also consulted.
} 
Countries Included

Countries that did not participate - or that did not provide data on persons convicted- in the first or the fourth editions of the European Sourcebook were excluded from the analyses because it was impossible to establish trends for the beginning or the end of the time series studied. The countries in that situation are the following: Armenia, Georgia, Iceland, Ireland, ${ }^{11}$ Slovakia, Spain, and Ukraine.

Countries that did not participate - or that did not provide data on persons convicted- in two or more consecutive editions of the European Sourcebook were excluded from the analyses because it was also impossible to establish reliable time series. The countries in that situation are the following: Lithuania, Luxembourg, Malta, The Former Yugoslav Republic of Macedonia, and Turkey.

Countries with a population of less than one million were excluded because they may experience substantial changes in crime rates from one year to another that are only due to the addition or the subtraction of a few persons convicted. As Iceland, Luxembourg and Malta had already been excluded for the reasons mentioned above, the only country in that situation is Cyprus.

Albania was excluded because its time series were heavily affected by the collapse of a pyramid lottery scheme in 1997 that led to a civil rebellion during which some 2,000 people were killed (Jarvis 2000). As a consequence, the Albanian figures for that period show sudden ups and downs that do not necessarily reflect the real number of offences committed. As an example, the rate of persons convicted for intentional homicide -including attempts- went from 1.9 per 100,000 population in 1995 to 8.8 in 1996, before going down to 3.7 in 1997 and raising again to 11.5 in 1998.

Denmark was excluded because the figures for persons convicted provided for the second edition included acquittals (Killias et al. 2003: 185) and therefore were not comparable to the ones provided in the previous and following editions of the European Sourcebook and to the ones provided by the rest of the countries, which include only persons convicted. The addition of convictions and acquittals corresponds to the input of cases received by the courts, which is also the output of the cases treated by the Public Prosecution Services that transmitted those cases to the courts. That measure could be useful for the study of the functioning of the criminal justice system -and, in particular, of its funnel structure-, but does not correspond to the type of measure used in this article to study crime trends (i.e. persons convicted by the courts).

As a consequence, the database used for our analyses includes information on 26 countries, of which 15 belong to Western Europe and 11 to Central and Eastern Europe. The Western European cluster includes the following countries: Austria, Belgium, England and Wales, Finland, France, Germany, Greece, Italy, Netherlands, Northern Ireland, Norway, Portugal, Scotland, Sweden, Switzerland. The Central and Eastern European cluster includes the following countries: Bulgaria, Croatia, Czech Republic, Estonia, Hungary, Latvia, Moldova, Poland, Romania, Russia, and Slovenia.

\footnotetext{
${ }^{11}$ Ireland presents also the particularity of showing zero persons convicted for intentional homicide in 1997 and, according to the second edition of the European Sourcebook, zero persons convicted for completed intentional homicide from 1995 to 1999 (although the first edition mentioned 0.3 and 0.1 persons convicted per 100,000 population in 1995 and 1996 respectively). The absence of convictions seems related to a particular way of recording the convictions pronounced because, during the 1990s, Ireland registered roughly 50 victims of homicide per year (Dooley 2001).
} 
Measuring the Influence of Changes in Data Recording Methods

Conviction statistics compiled in the European Sourcebook refer to the number of persons convicted and not to the number of sentences imposed. None of the countries included in our analyses reported a change in that counting unit during the period under study.

When counting convictions, most countries apply the principal offence rule, which means that, if a person is convicted for several offences, only the most serious one is counted. The exceptions are Belgium, Hungary, and Switzerland, which count each offence. ${ }^{12}$ At the same time, eight countries ${ }^{13}$ record court decisions before any appeal, $15^{14}$ record them after appeals have been exhausted, and three ${ }^{15}$ did not provide information on that issue. The principal offence rule and the moment in which data are collected for the statistics would have a major influence if we were comparing crime rates across countries, but, as we are interested in crime trends, we only need to control whether those rules suffered any changes -that could provoke spurious modifications of the trends- during the period under study. In practice, none of the countries included in our analyses reported such changes.

Finally, Wittebrood and Junger (2002) have suggested that increases in police recorded violent offences may be partially due to increased computerization, which facilitates registration. ${ }^{16}$ This hypothesis could be extrapolated to conviction statistics as most countries have changed from paper statistics to computer statistics since the end of the 1980s. In that context, the influence of computerization should be homogeneous across offences, in the sense that the number of persons convicted for each type of offence should increase. However, that hypothesis cannot be fully tested with the data available for this research, which do not include details on the moment in which the different national statistical systems were computerized.

\section{Measuring the Influence of Changes in Legal Definitions}

It has been mentioned before that changes in legal definitions can affect the trends shown by conviction statistics. As each edition of the European Sourcebook includes a question about the eventual changes in the legal definitions of offences introduced in each country, it was possible to check whether, between 1990 and 2006, such changes took place in the countries and offences studied here and whether they had an influence on the number of persons convicted. Those changes are presented in the two following chapters. Nevertheless, we must warn the reader that these lists of changes may not be exhaustive, as some changes may have not been reported by the national correspondents in charge of answering the European Sourcebook questionnaire.

\section{Changes in Legal Definitions in Western Europe}

The concept of rape was enlarged in Switzerland in 1992, in France in 1994, in Germany in 1997 and in Greece in 2006. One of the main modifications introduced in Switzerland,

\footnotetext{
${ }_{12}$ The following five countries did not provide information regarding whether they apply or not the principal offence rule: Croatia, Estonia, Latvia, Moldova and Norway.

${ }^{13}$ England and Wales, Finland, the Netherlands, Northern Ireland, Portugal, Russia, Scotland and Sweden.

${ }^{14}$ Austria, Belgium, Bulgaria, Croatia, Czech Republic, Estonia, France, Germany, Greece, Hungary, Italy, Poland, Romania, Slovenia and Switzerland.

${ }_{15}$ Latvia, Moldova and Norway.

${ }^{16}$ A similar, but broader, hypothesis has been suggested by van Dijk (2008), who considers that "The number of crimes officially recorded by the police goes up with modernization because of the strengthening of the official systems of social control, including their capacity to record crime and invite victim reporting. Countries record more crimes to the extent that they are "modern'" (van Dijk 2008: 33).
} 
Germany and Greece was the inclusion of violent intra-marital sexual intercourse in that concept. Such changes did not have major effects on the number of persons convicted for rape. In Germany, their number remained stable between 1997 and 1999, and the same is true for France between 1993 and 1995. In Greece, the modification intervened during the last year of the series studied here, for which no figures were provided. Finally, in Switzerland, contrary to what was expected, the number of persons convicted for rape decreased by $16 \%$ between 1992 and 1994 .

As far as assault is concerned, France introduced a new Criminal Code in 1994, which changed the sanctions according to the physical injuries produced and, in 2003, the French definition of assault was enlarged in order to include new aggravating circumstances. Comparing 1995 to 1993, the number of persons convicted for assault in France decreased by $50 \%$, but two years later, in 1997, their number had increased again and was already higher than in 1993. The modifications introduced in 2003 were followed by an increase of $26 \%$ of the persons convicted in 2004 , and their number continued to increase after that.

Regarding property offences, in Switzerland, since the beginning of 1995, theft of small value is considered a misdemeanour pursued only if the victim press charges. In that perspective, comparing 1994 to 1995, the number of persons convicted for theft in Switzerland decreased by $21 \%$, but their number increased again from 1996 until 1999.

Finally, as far as drug offences are concerned, in Italy, a law of 1990 introduced the criminalization of personal consumption, but that law was abolished in 1994, following a referendum. In that context, between 1990 and 1991, there was an increase of 84\% of the number of persons convicted for drug offences. Then, in 1994 and 1995 there was a decrease of roughly $10 \%$-compared to $1993-$ but, in 1996 , the number of persons convicted for drug offences in Italy was already higher than in 1993. In France, the Criminal Code of 1994 introduced a specific offence of organized traffic. A comparison of 1993 and 1995 shows that the new Criminal Code was followed by a decrease of $15 \%$ in the number of persons convicted for drug offences, but in 1996 their number increased again and was already higher than in 1993. In Austria, in 1998, the definition of drug offences was enlarged in order to criminalize possession and handling of psychotropic substances and raw material. However, the number of persons convicted for drug offences in Austria decreased by 13\% between 1997 and 1998, and it remained at that level until 2001, when it went up again to rejoin the level of 1997 and, after that, it continued to increase until the end of the series.

In sum, in Western Europe, changes in legal definitions had only punctual effects that, in general, did not alter the overall trend observed on convictions for each type of offence.

\section{Changes in Legal Definitions in Central and Eastern Europe}

Most Central and Eastern European countries introduced major modifications in their criminal law, or brand new Criminal Codes, after the breakup of the Soviet Union. For example Croatia introduced a new Criminal Code in 1998, Estonia in 2002, Latvia in 1999, Moldova in 2003, Poland in 1998, and Romania in 2005. Although such changes should have a minor impact in very serious offences such as homicide, they surely had some effect on the trends in convictions for other offences. Leaving aside the abolition of the death penalty or the introduction of a moratorium on executions, as well as crimes not covered by this article -such as computer related crimes and corruption-, changes in the criminal law in Central and Eastern European countries affected mainly drug offences, sexual offences, and property offences. 
In particular, the definition of sexual offences was enlarged in Croatia in 1998, in the Czech Republic in 2000, and in Romania in 2000. The modifications regarded the inclusion of sexual marital intercourse (for example, in Croatia) and the inclusion of men as possible victims of crime (for example, in Romania and the Czech Republic). The enlargement of the definition of rape did not lead to increases in convictions for rape.

Special laws or sections of the Criminal Code on drug offences were introduced in most Central and Eastern European countries since the beginning of the 1990s, and the definition of drug trafficking was enlarged in 1998 in Croatia, in 2000 in the Czech Republic, in 2003 in Moldova, in 1997 and in 2000 in Poland, in 1996 and in 2000 in Romania, and between 1996 and 2000 in Russia. Possession of drugs for personal use was decriminalized in Estonia in 2002, in Moldova in 2003, in Hungary in 1996, in Poland in 1997 and in Russia by the end of the 1990s. However, both Hungary and Poland criminalized it again in 1996 and 2000 respectively. Croatia criminalized possession of drugs for personal use in 2001. All these modifications did not alter the general upwards trend observed in all countries in drug offences.

Theft of small value is considered in some countries as a misdemeanour and not as a criminal offence. As a consequence, it is not included in criminal statistics. In that context, the threshold to qualify theft as a criminal offence was raised in 1995 in Poland (where it was multiplied by ten), in 2000 in the Czech Republic in 2002 (where it was fixed at 5000 CZK or approximately 170 Euro), and in Russia in 2002 (where it was fixed at 60 Euro, which represented five times the minimum wage at that period). These modifications may have played a role in the decrease in theft observed in Central and Eastern European countries since 2000 (see Fig. 7).

For some countries and some offences, the changes in legal definitions introduced major modifications in the trends shown by conviction statistics. In such cases, the country was excluded from the analysis of the offences affected by such changes. Thus, in Estonia, the introduction of the new Criminal Code in 2002 made it impossible to compare most of the offences registered since 2003 with the ones registered in previous years. For that reason, Estonia has only been included in the analysis of trends on intentional homicide. The same is true for Moldova -which presented also a lot of gaps in its time series for some offences-, where the changes introduced by the 2003 Criminal Code had also a major impact on the country's crime rates. Latvia was in a similar situation due to the substantial changes introduced since the early 1990s and, as a consequence, was excluded from the analyses of assault, robbery and theft.

\section{Measuring the Role of the Public Prosecution Services}

We have seen that de Candolle (1832/1987b) had already identified differences in criminal proceedings as one of the sources of distortion of international comparisons of conviction statistics. Nowadays, the Public Prosecution Services are considered a key player in such proceedings (Jehle et al. 2008), especially because some cases may not be transferred to a court if they are solved through a sanction imposed by those services. The same is true -as it was suggested by an anonymous reviewer of this paper- for informal measures or sanctions imposed by the police.

According to the metadata included in the European Sourcebook, all countries included in this analysis do not count sanctions and measures imposed by the police nor do they count sanctions imposed by the prosecutors that do not lead to a formal verdict. On the contrary, most countries count sanctions imposed by the prosecutor, or by the court but on demand of the prosecutor - a procedure known sometimes as penal order and that implies a 
simplified procedure, similar to a plea bargain, in which the offender accepts the sanction proposed by the prosecutor- that lead to a formal verdict which will be counted as a conviction. The exceptions are Greece, Italy and England and Wales, which did not include them, and the Netherlands, where this type of sanctions does not exist.

\section{Interpolation and Extrapolation}

Among the countries included in our analyses, some were unable to provide data for each and every year of the time series. In that context, for those countries that had up to three contiguous missing years, we used linear interpolation to calculate the missing values between years. ${ }^{17}$ When the last year of the series was not available, we extrapolated it by repeating the previous available year. ${ }^{18}$ Linear interpolation and extrapolation are the standard procedures for the replacement of missing data. They are used, for example, by the World Health Organization for the calculation of regional averages of homicides according to health statistics (WHO 2010).

When there were only minor differences between the figures provided in two consecutive editions of the European Sourcebook, we used the figures of the latest edition, which is always considered as an update of the previous one (see, for example, Killias et al. 2003: 5).

\section{Weighting Procedure}

Data have been counterchecked in order to identify sudden variations from one year to another and, especially, from one edition of the European Sourcebook to another. Such variations could be due to changes in legal definitions or statistical counting rules that were not reported by the national correspondents that filled in the European Sourcebook questionnaire, or to the fact that the country included (or excluded) in one edition of the European Sourcebook some sub-categories of an offence that were excluded (or included) in the previous one. Three countries (England and Wales, Moldova, and Romania) presented time series with major variations in the rate of persons convicted for intentional homicide (including attempts) in different editions of the European Sourcebook.

However, as each edition of the European Sourcebook includes also data for the last year included in the previous edition (for example, 2003 is included in the 3rd and the 4th edition), it is possible to correct some of these sudden variations by weighting the data accordingly. The case of England and Wales is presented as an example in Fig. 1. In the first edition of the European Sourcebook (CoE 1999: 116), covering the years 1990 to 1996, its rate for total intentional homicide varied from 0.9 in 1990 to 1.1 in 1996 (the annual rates, including a second decimal not shown in the printed edition of the European Sourcebook, were the following: 0.90, 0.99, 1.03, 1.03, 0.98, 0.99, and 1.10). In the second edition (Killias et al. 2003: 102), covering the years 1995 to 2000, the rate oscillated between 0.5 in 1995 to 0.6 in 2000 (the annual rates were: $0.53,0.61,0.67,0.61$, and 0.63 ). As it can be seen, there was a huge difference between the figure for 1995 in the first edition (0.99) and the one included in the second edition for the same year (0.53). The same

\footnotetext{
17 Taking as an example the case of total intentional homicide, we interpolated the figures for France in 1994, Estonia in 2005 and 2006, Greece in 1998, 1999, 2003 and 2004, Latvia from 2000 to 2002, Norway in 1995, 1996, and from 2000 to 2002, and Russia in 1995, 2001 and 2002.

${ }^{18}$ Taking once more the case of total intentional homicide as an example, we extrapolated the figures for Belgium in 2005 and 2006, and Greece, Italy and Scotland in 2006.
} 


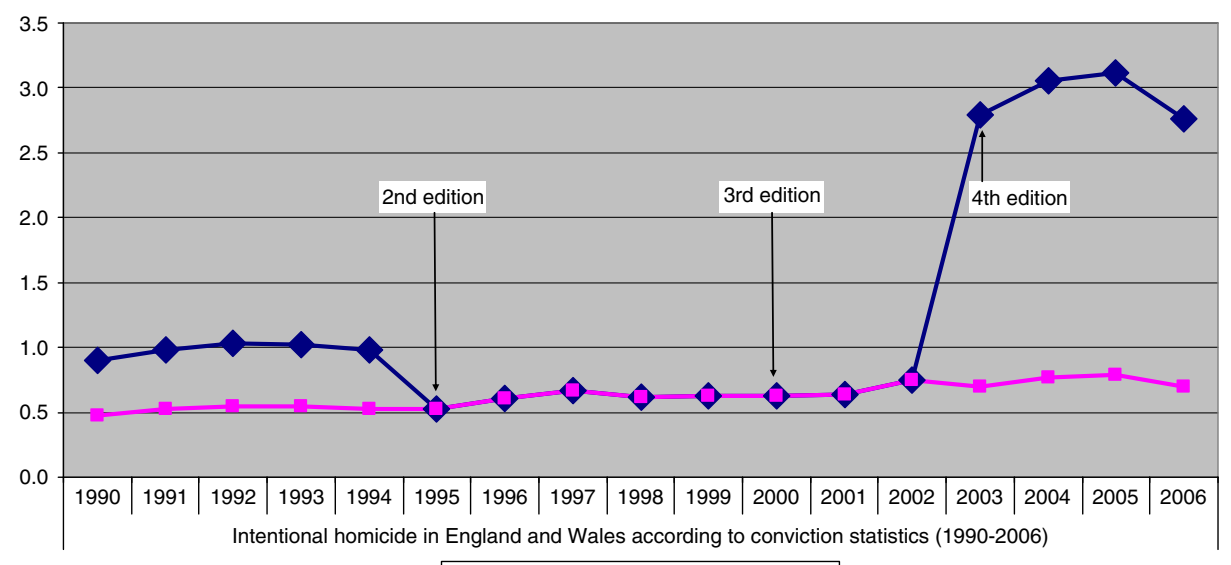

$\rightarrow$ Before weighting - After weighting

Fig. 1 Persons convicted for intentional homicide (including attempts) in England and Wales according to conviction statistics (1990-2006), before and after weighting

is true for 1996, which presented a rate of 1.10 in the first edition and a rate of 0.61 in the second one. This problem did not arise between the second and the third edition of the European Sourcebook as the figure provided for 2000 (0.61) is the same in both editions. However, between the third and the fourth edition, there is again a huge difference as the figure for 2003 was 0.70 in the third edition but 2.79 in the fourth one. How can these big differences be explained?

According to the authors of the European Sourcebook, the second edition is an updated version of the first one (Killias et al. 2003: 5), the third one a partial update of the second one (Aebi et al. 2006: 5), and the fourth one an extended update of the third one (Aebi et al. 2010: 5). This implies that, when different figures were provided for the same year in different editions of the Sourcebook, the figures included in the latest edition are supposed to be more reliable than the ones included in the previous one. Nevertheless, when there are big changes in the figures provided for the same year in different editions, the countries usually provide an explanation. That was not the case of England and Wales, which did not explain the sudden changes in the level of its rates. Studying the time series, and taking into account that such changes could be due to the inclusion or the exclusion of a sub-category of an offence in the different editions of the European Sourcebook, we came to the conclusion that the most plausible explanation is that the category of assault leading to death was included in the first and the fourth editions, but excluded in the second and the third ones. That explanation is corroborated by the fact that the time series for assault in England and Wales present similar variations, but in the opposite way.

If the figures were kept as published in the European Sourcebook, it would be impossible to use them for a comparison of crime trends. As can be seen in Fig. 1 (series before weighting), they would show a decrease of 47\% between 1994 and 1995 and an increase of almost $400 \%$ between 2002 and 2003. As a consequence, the country should be excluded from the analysis. Nevertheless, it is clear that the figures for the first and the fourth edition are higher because the definition applied is larger than the one used for the second and the third edition. Moreover, as we are interested in crime trends and not in crime levels, there is no reason for rejecting the application of a weighting procedure that eliminates the distortions introduced by the inclusion or the exclusion of a subcategory. Such procedure would allow us to produce a comparable trend for the whole period. In that 
perspective, the assumption that we would be making while weighting the data is that the general category of the offence did not change in a different way than its subcategory.

For these reasons, we decided to weight the data for the first and the four editions according to the figures for the second and the third edition. Thus, in our time series, the figure used for 1995 is the one provided by the second edition (0.53), which represented $53.19 \%$ of the figure provided by the first edition (0.99). Accordingly, the rest of the figures provided by the first edition were reduced in the same proportion. This produced a new series $(0.48,0.52,0.55,0.55,0.52$ and 0.53$)$ which shows the same trend as the one provided by the original figures but a similar level to the one showed in the second one (see Fig. 1, series after weighting). The same procedure was applied to weight the data for the fourth edition according to the level of the third one. In that case, a coefficient of 0.25 was applied (the figure for 2003 was 0.70 according to the third edition and 2.79 according to the fourth edition). Once more, after the weighting procedure, the levels are homogeneous between the two editions of the Sourcebook and the trend remains the same as before the weighting. According to the fourth edition, between 2003 and 2007, the rates were 2.79, $3.06,3.12,2.76$ and 2.74 , while, according to the weighted figures, they are $0.70,0.77$, $0.78,0.695$ and 0.689 .

The same weighting procedure -but in the opposite way, because it was necessary to give more weight to the figures from the first and the fourth edition- was applied to the rate of persons convicted for assault in England and Wales. As it has been said, this inconsistency in the trends corroborates the hypothesis that the category of assault leading to death was twice included in the total figure for intentional homicide and twice included in the total figure for assault. In addition, this weighting procedure was applied to persons convicted for intentional homicide (including attempts) in Moldova from 1996 to 1999 and in Romania from 1997 to 1999.

Apart from that, the time series for persons convicted for assault in Croatia and Romania were discarded because they were inconsistent and could not be weighted. The same is true for persons convicted for drug offences in Switzerland.

\section{Statistical Measures}

Finally, in order to reduce even more the negative impact -in terms of the reliability of the time series- of changes in data recording methods or legal definitions in a particular country, our analyses are based on trends in groups of countries. Thus, we consider (a) Europe as a single cluster, which is then divided in a (b) Western European cluster and a (c) Central and Eastern European cluster.

In that context, we use the rates of persons convicted per 100,000 population in each country to compute geometric means for each cluster of countries, each offence, and each year. The geometric mean represents the average of the $n^{\text {th }}$ root of $n$ non-negative numbers (Dodge 1993: 248-9). According to Dodge (1993: 248-9), the geometric mean is used in particular to calculate the average of ratios and reduces the influence of extreme values (outliers). As our data includes some outliers, the geometric mean was preferred to the arithmetic mean, which is extremely sensitive to the presence of such outliers. Moreover, as the analyses are based on rates per 100,000 population, the geometric mean was also preferred to the median.

Apart from that, we include two measures of the evolution of the rates of persons convicted during the time frame of our analyses. The first one is the percentage change between 1990 and 2006, which is based on a direct comparison of the rates for both years. The second one is the average annual percent change (AAPC), also known as average 
annual variation and annual growth rate. This measure is appropriated for time series data that do not show a linear trend; it estimates the logarithmic growth of the model (Sarma 2001: 221). By taking into account the rates of each of the years included in the series, the AAPC provides an estimation of the overall trend during the period under study in terms of the constant percentage of increase -or decrease- experienced during each year of the series.

All our calculations are based upon unrounded numbers. This means that they include all the decimals that could not be shown in the printed versions of the European Sourcebook and in Figs. 2, 3, 4, 5, 6, 7 and 8.

\section{Available Data}

Table 1 presents the time series available for each country and each offence. Unavailable data have been indicated as such (N.A.) in the table. When data were available, the table indicates the percentage change and the average annual percent change between 1990 and 2006 for each offence and each country. For example, Belgium provided completed series for total intentional homicide, assault, rape, and theft. In the case of total intentional homicide, the rate of persons convicted in Belgium in 2006 was $128 \%$ higher than in 1990 , and the average annual increase between 1990 and 2006 was $6.4 \%$. In the case of assault, the 2006 rate was $52 \%$ higher than the rate of 1990 , and the average annual increase during that period was $1.4 \%$. Table 1 also indicates the number of countries included in each analysis and, for each cluster of countries studied, the geometric mean of their percentage change and average annual percent change. For example, in the case of total intentional homicide, 26 countries provided data and the rate of persons convicted for that offence in Europe in 2006 was $23 \%$ higher than in 1990, while the average annual increase between 1990 and 2006 was $0.6 \%$. At the same time, in Western Europe, the 2006 rate was 14\% higher than the rate of 1990, and the average annual increase was $0.2 \%$; while in Central and Eastern Europe the 2006 rate was 36\% higher than the rate of 1990, and the average annual increase was $1.2 \%$.

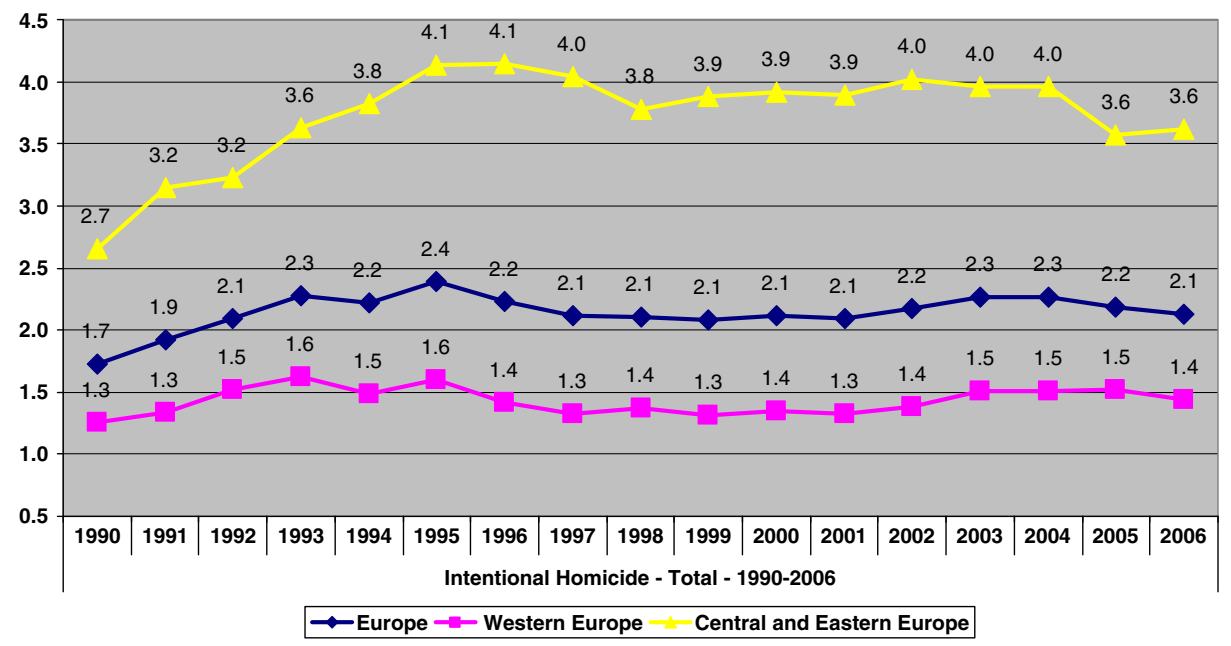

Fig. 2 Persons convicted for intentional homicide (including attempts) per 100,000 population between 1990 and 2006 in 26 European countries (Geometric means) 


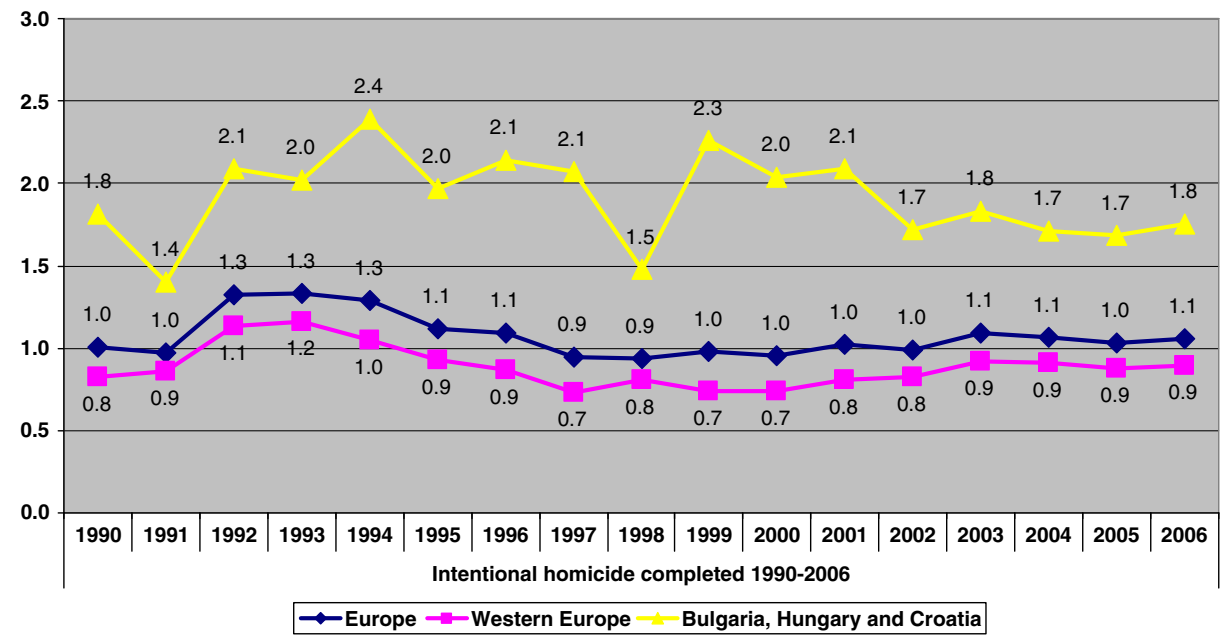

Fig. 3 Persons convicted for completed intentional homicide per 100,000 population between 1990 and 2006 in 12 European countries (Geometric means)

\section{Findings}

Intentional Homicide (Including Attempts)

The European Sourcebook is based on a questionnaire sent to national correspondents in each country. The questionnaire includes a standard definition of each offence and a series of sub-categories of that offence that should be included or excluded by the correspondents when providing the figures for the publication. According to the standard definition, intentional homicide means "intentional killing of a person" (Aebi et al. 2010: 349). In principle, figures include assault leading to death, euthanasia, infanticide, and attempts; but

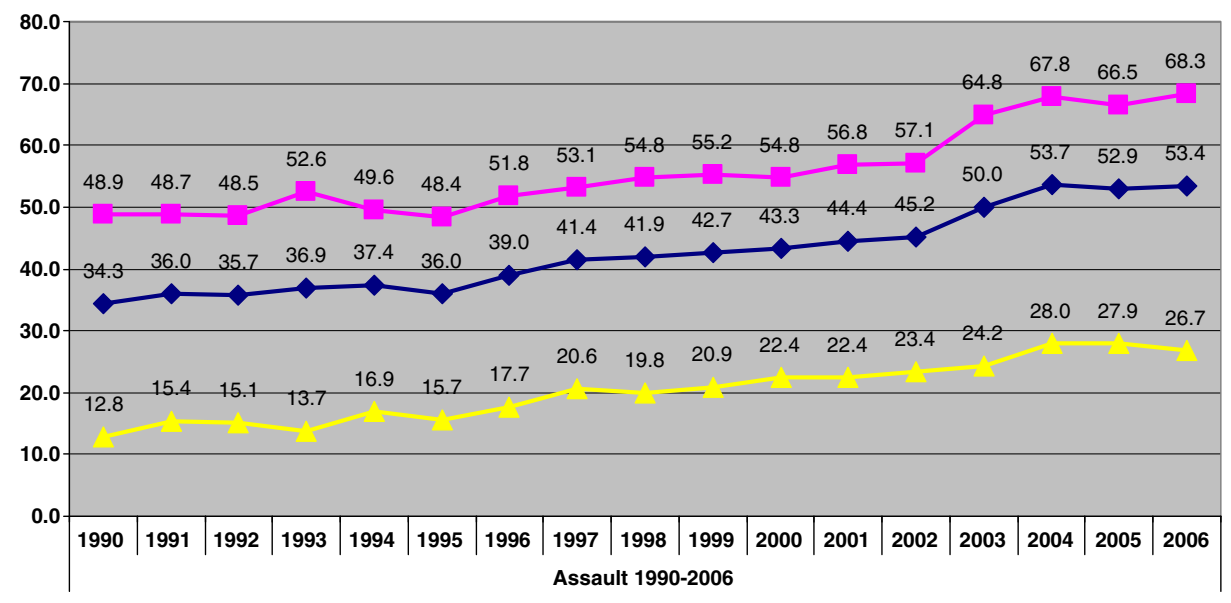

Europe $\rightarrow-$ Western Europe $\_$Central and Eastern Europe

Fig. 4 Persons convicted for assault per 100,000 population between 1990 and 2006 in 19 European countries (Geometric means) 


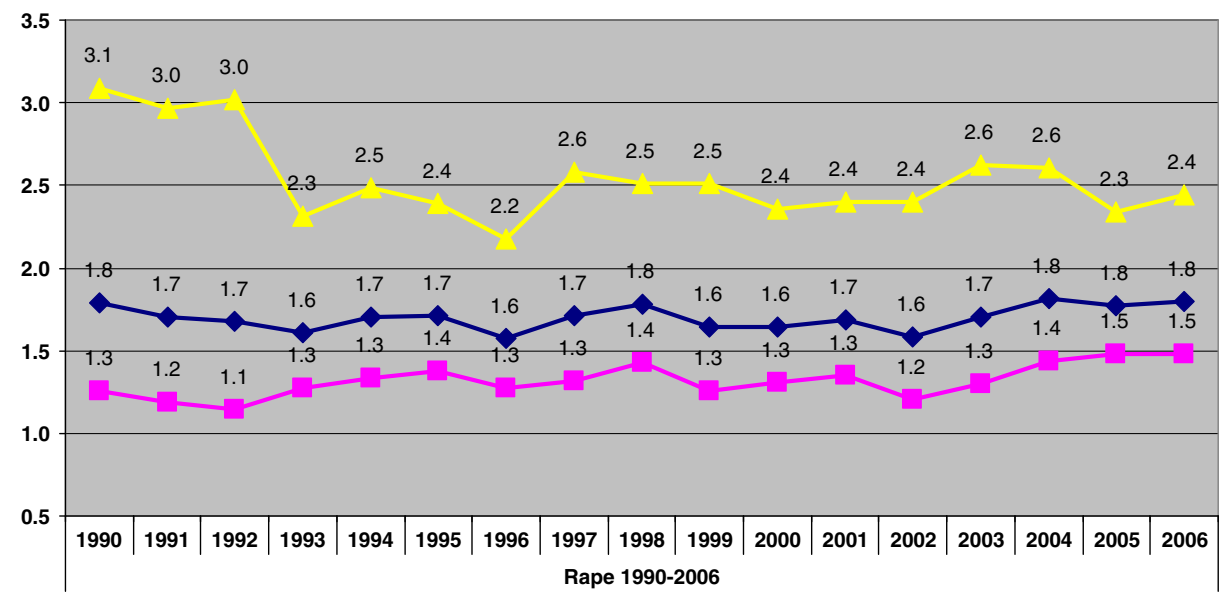

$\rightarrow$ Europe $\rightarrow-$ Western Europe $\leadsto$ Central and Eastern Europe

Fig. 5 Persons convicted for rape per 100,000 population between 1990 and 2006 in 23 European countries (Geometric means)

they exclude assistance with suicide. The total rate of intentional homicides is completely inappropriate for cross-national comparisons of crime because the percentage of attempts varies widely from one country to another (Aebi 2010); however, it can be used for the comparisons of trends. Figure 2 shows trends in persons convicted for intentional homicide (including attempts), for which data are available for the 26 countries included in our analyses.

In Western European countries, the rate of persons convicted per 100,000 population for intentional homicide registered an increase of 29\% from 1990 to 1993, remained relatively stable at the 1993 level until 1995, and decrease by $12 \%$ in 1996. Since then, the rate has been relatively stable, oscillating between 1.3 and 1.5 convicted persons per 100,000 population. By 2006, the rate of persons convicted for intentional homicide was $14 \%$ higher

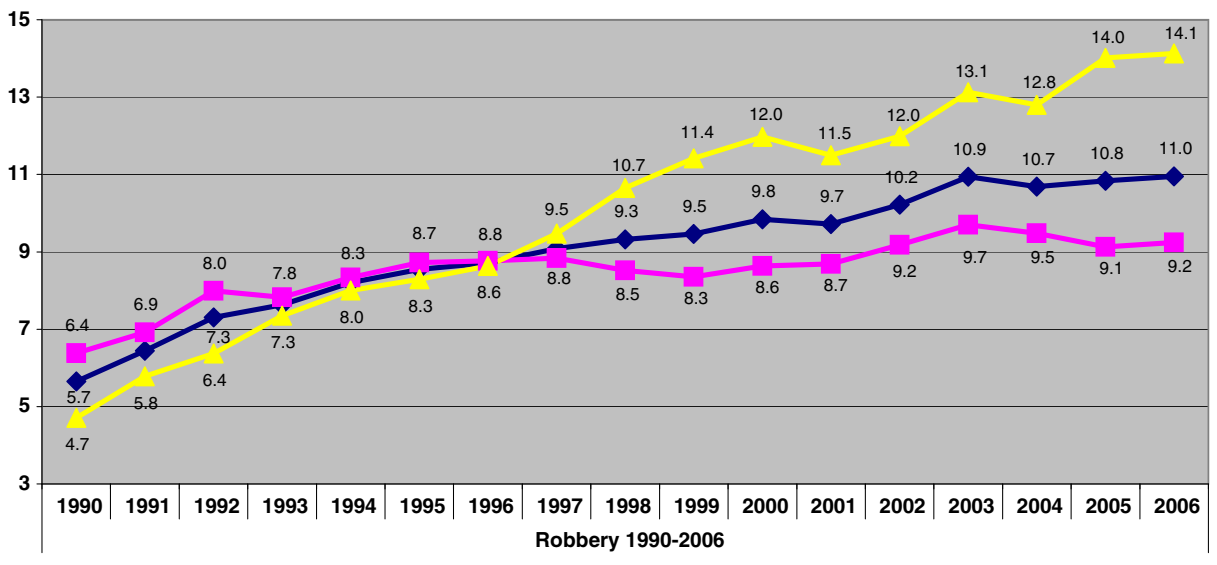

$\rightarrow$ Europe -- Western Europe - Central and Eastern Europe

Fig. 6 Persons convicted for robbery per 100,000 population between 1990 and 2006 in 20 European countries (Geometric means) 


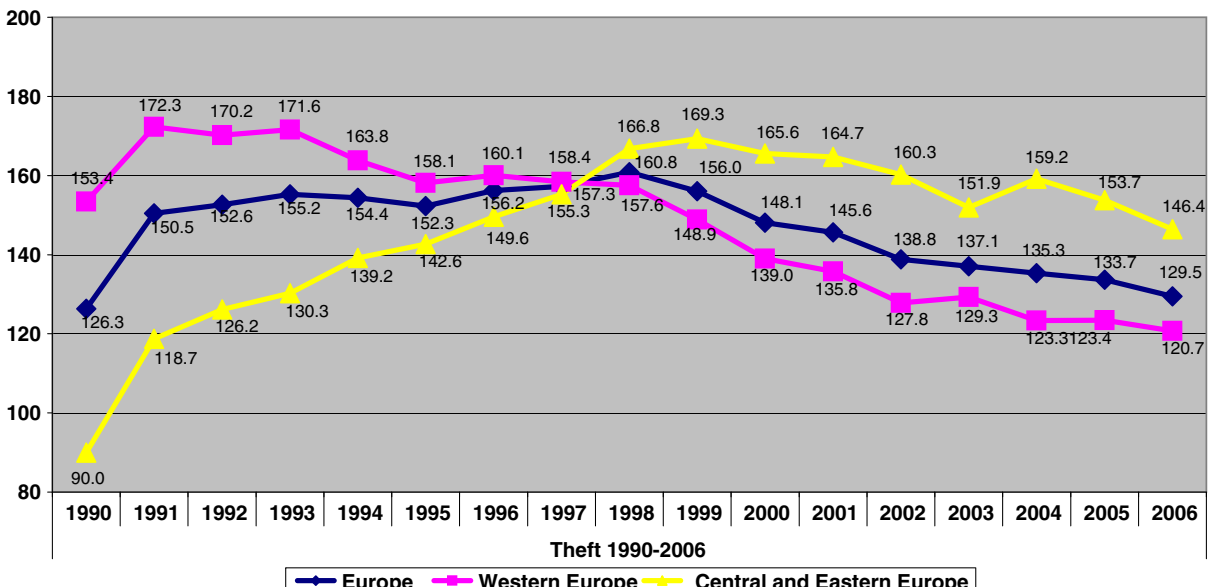

Fig. 7 Persons convicted for theft per 100,000 population between 1990 and 2006 in 22 European countries (Geometric means)

than in 1990, and the average annual increase between 1990 and 2006 was $0.2 \%$. An individual analysis shows that eight countries experienced higher rates in 2006 than in 1990, with increases ranging from $21 \%$ to $165 \%$ (Austria, Belgium, Italy, Netherlands, Sweden, Switzerland, England and Wales, and Scotland), two remained stable (Finland and Germany), and five experienced decreases ranging from $-22 \%$ to $-48 \%$ (France, Greece, Norway, Portugal, and Northern Ireland).

In Central and Eastern Europe, the rate of persons convicted per 100,000 population for intentional homicide increased by 56\% (from 2.7 to 4.1) between 1990 and 1996 and, despite a punctual decrease in 1998 (3.8 persons convicted per 100,000 population), remained relatively stable between 1997 and 2004, oscillating between 3.9 and 4.0, before

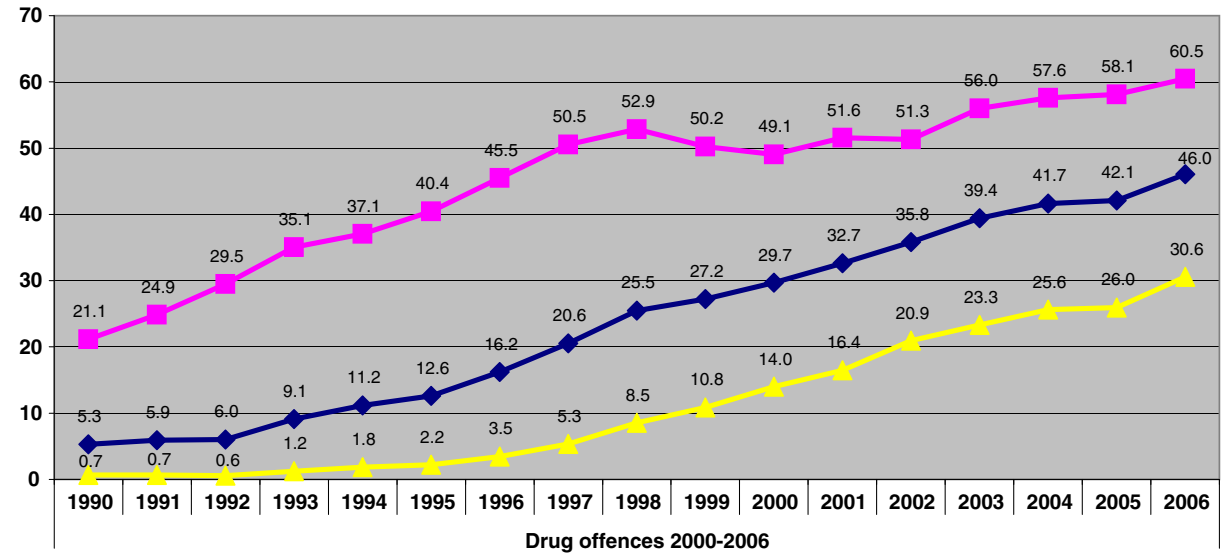

$\rightarrow$ Europe -- Western Europe - Central and Eastern Europe

Fig. 8 Persons convicted for drug offences per 100,000 population between 1990 and 2006 in 20 European countries (Geometric means) 
Table 1 Percentage change (1990-2006) and average annual percent change between 1990 and 2006 in the rates of persons convicted per 100,000 population, by offence and by country

\begin{tabular}{|c|c|c|c|c|c|c|c|c|c|c|c|c|c|c|}
\hline & \multicolumn{4}{|c|}{ Intentional homicide } & \multicolumn{2}{|c|}{ Assault } & \multicolumn{2}{|l|}{ Rape } & \multicolumn{2}{|c|}{ Robbery } & \multicolumn{2}{|l|}{ Theft } & \multicolumn{2}{|c|}{ Drug offences } \\
\hline & \multicolumn{2}{|c|}{ Total } & \multicolumn{2}{|c|}{ Completed } & \multirow[b]{2}{*}{$\mathrm{PC}$} & \multirow[b]{2}{*}{ AAPC } & \multirow[b]{2}{*}{$\mathrm{PC}$} & \multirow[b]{2}{*}{ AAPC } & \multirow[b]{2}{*}{$\mathrm{PC}$} & \multirow[b]{2}{*}{ AAPC } & \multirow[b]{2}{*}{$\mathrm{PC}$} & \multirow[b]{2}{*}{ AAPC } & \multirow[b]{2}{*}{$\mathrm{PC}$} & \multirow[b]{2}{*}{ AAPC } \\
\hline & $\mathrm{PC}$ & AAPC & $\mathrm{PC}$ & AAPC & & & & & & & & & & \\
\hline \multicolumn{15}{|l|}{ Western Europe } \\
\hline Austria & 21 & -1.0 & 9 & -2.3 & -45 & -5.6 & 0 & -1.1 & 44 & 1.3 & -43 & -4.0 & 377 & 8.4 \\
\hline Belgium & 128 & 6.4 & N.A. & & 52 & 1.4 & 59 & 2.7 & N.A. & & 45 & 0.9 & N.A. & \\
\hline Finland & 0 & 0.0 & -36 & -1.8 & 14 & 1.7 & 87 & 2.7 & 0 & -0.4 & 1 & -0.3 & 867 & 14.3 \\
\hline France & -28 & -1.7 & N.A. & & 48 & 2.9 & 123 & 4.8 & N.A. & & -26 & -2.1 & 76 & 2.6 \\
\hline Germany & 0 & -0.4 & N.A. & & 114 & 5.1 & 4 & 0.2 & 62 & 2.2 & -23 & -2.2 & 92 & 3.9 \\
\hline Greece & -31 & -3.2 & -44 & -4.1 & -78 & -7.7 & -12 & -3.6 & 211 & 5.2 & -27 & -2.9 & 87 & 4.2 \\
\hline Italy & 165 & 6.4 & 149 & 6.7 & 658 & 11.9 & 190 & 4.4 & 82 & 3.0 & 40 & 1.3 & 160 & 3.5 \\
\hline Netherlands & 97 & 3.6 & N.A. & & 138 & 7.0 & 26 & 5.3 & 44 & 2.7 & 1 & -0.5 & 196 & 8.0 \\
\hline Norway & -48 & -3.1 & N.A. & & N.A. & & N.A. & & N.A. & & N.A. & & N.A. & \\
\hline Portugal & -22 & -3.9 & -21 & -3.4 & 61 & 5.0 & -77 & -7.7 & 308 & 7.3 & 17 & -3.3 & 101 & 2.7 \\
\hline Sweden & 22 & 1.5 & N.A. & & 18 & 0.0 & 131 & 2.5 & 50 & 2.6 & -32 & -3.2 & 181 & 6.6 \\
\hline Switzerland & 70 & 1.9 & 79 & 0.2 & 253 & 8.7 & 50 & 3.6 & 10 & -0.4 & -34 & -3.1 & N.A. & \\
\hline $\begin{array}{l}\text { UK: England } \\
\text { \& Wales }\end{array}$ & 45 & 2.8 & -9 & -1.7 & -19 & -0.4 & 51 & 2.8 & 60 & 3.1 & -40 & -2.1 & 53 & 4.5 \\
\hline $\begin{array}{l}\text { UK: Northern } \\
\text { Ireland }\end{array}$ & -40 & -7.8 & 29 & -1.9 & 57 & 2.8 & -72 & -6.3 & -39 & -2.5 & -58 & -6.2 & 552 & 6.7 \\
\hline UK: Scotland & 42 & 1.8 & 31 & 1.2 & 6 & 0.6 & 32 & 3.9 & -32 & -2.2 & -46 & -3.9 & 138 & 4.4 \\
\hline \multicolumn{15}{|c|}{ Central and Eastern Europe } \\
\hline Bulgaria & 26 & 1.1 & 11 & 0.8 & 179 & 8.6 & 18 & 1.8 & 479 & 12.1 & 287 & 11.0 & 61505 & 69.3 \\
\hline Croatia & -19 & -3.1 & -16 & -1.6 & N.A. & & -39 & 1.1 & 291 & 8.7 & 10 & 2.3 & 4655 & 35.8 \\
\hline Czech Republic & 66 & 4.6 & N.A. & & 91 & 4.3 & -26 & -0.3 & 199 & 5.8 & 305 & 3.9 & 5072 & 31.3 \\
\hline Estonia & 50 & 1.9 & N.A. & & N.A. & & N.A. & & N.A. & & N.A. & & N.A. & \\
\hline Hungary & 9 & 0.1 & -2 & -0.5 & 89 & 2.9 & -57 & -4.4 & 52 & 1.9 & 30 & 0.2 & 7509 & 35.0 \\
\hline Latvia & 3 & 0.8 & N.A. & & N.A. & & -40 & -2.9 & N.A. & & N.A. & & 1478 & 25.6 \\
\hline Moldova & 120 & 4.0 & N.A. & & N.A. & & N.A. & & N.A. & & N.A. & & N.A. & \\
\hline Poland & 147 & 4.4 & N.A. & & 251 & 5.8 & 49 & 1.9 & 246 & 9.1 & 98 & 4.1 & 8718 & 26.6 \\
\hline Romania & -21 & -1.9 & N.A. & & N.A. & & -38 & -4.5 & 195 & 3.2 & 10 & -1.8 & N.A. & \\
\hline Russia & 83 & 3.5 & N.A. & & N.A. & & -49 & -4.9 & 156 & 4.8 & 96 & 2.4 & 1071 & 16.2 \\
\hline Slovenia & 35 & -1.8 & N.A. & & 14 & 2.9 & 88 & 4.4 & 143 & 6.4 & -48 & -3.3 & 955 & 21.8 \\
\hline $\begin{array}{l}\text { Geometric mean } \\
\text { Europe }\end{array}$ & 23 & 0.6 & 6 & -0.7 & 56 & 2.9 & 1 & 0.2 & 94 & 3.6 & 2 & -0.6 & 769 & 15.5 \\
\hline $\begin{array}{l}\text { Geometric mean } \\
\text { West }\end{array}$ & 14 & 0.2 & 9 & -0.8 & 40 & 2.3 & 18 & 0.9 & 45 & 1.8 & -21 & -2.3 & 186 & 5.8 \\
\hline $\begin{array}{l}\text { Geometric mean } \\
\text { East/Cent. }\end{array}$ & 36 & 1.2 & -3 & -0.4 & 110 & 4.9 & -21 & -0.9 & 200 & 6.4 & 63 & 2.3 & 4493 & 31.9 \\
\hline $\begin{array}{l}\text { Number of } \\
\text { countries } \\
\text { included }\end{array}$ & 26 & & 12 & & 19 & & 23 & & 20 & & 22 & & 20 & \\
\hline
\end{tabular}

Note: Calculations are based upon unrounded numbers (i.e. including the decimals not shown in Figs. 2, 3, 4, $5,6,7$ and 8)

Abbreviations: PC: Percent change 1990-2006; AAPC: Average annual percent change between 1990 and 2006; N.A.: Not Available 
decreasing by $10 \%$ in $2005-2006$ to reach a rate of 3.6 . This rate was $36 \%$ higher than the one registered in 1990, while the average annual increase between 1990 and 2006 was $1.2 \%$. A country level analysis shows that nine out of 11 Eastern and Central European countries (Bulgaria, Czech Republic, Estonia, Latvia, Moldova, Poland, Russia and Slovenia) registered higher levels of persons convicted for intentional homicide, ranging from 3 to $147 \%$, in 2006 than in 1990. Only Croatia and Romania showed decreases of $19 \%$ and $21 \%$ respectively.

The general European trend is influenced at the beginning of the series (1990 to 1995) by the increase registered in both regions but, since 1996, it remains stable oscillating between 2.1 and 2.3 during 11 years. The 2006 European homicide rate was $23 \%$ higher than the rate of 1990 , while the average annual increase was $0.6 \%$.

\section{Completed Intentional Homicide}

Only 12 countries -nine in Western Europe and three in Central Europe (for details, see Table 1)- provided data on the subcategory of completed intentional homicide (i.e. excluding attempts). Their trends are shown in Fig. 3.

In Western European countries, the rate of persons convicted for completed intentional homicide increased by $41 \%$ between 1990 and 1993 (from 0.8 to 1.2 persons convicted per 100,000 population) and decreased in a similar proportion from the following year until 1997, when it reached a level comparable to the one registered in 1990, and remained relatively stable (oscillating between 0.7 and 0.8) until 2002. Between 2003 and 2006 the trend remained also relatively stable, but at a slightly higher lever $(0.9$ persons convicted per 100,000 population). In 2006, the rate of persons convicted for completed intentional homicide was $9 \%$ higher than in 1990, although the average annual percent change indicates a $0.08 \%$ annual decrease from 1990 to 2006. In particular, five countries (Austria, Italy, Switzerland, Northern Ireland and Scotland) registered higher rates in 2006 than in 1990, with increases ranging from 9\% to 149\%; but four other countries (Finland, Greece, Portugal and England and Wales) registered lower rates, ranging from $-9 \%$ to $-44 \%$.

Bulgaria, Hungary and Croatia present a trend punctuated by ups and downs in which, leaving aside punctual decreases in 1991 and 1998, it is possible to distinguish three main periods. An increase of 32\% between 1990 and 1994 (from 1.8 to 2.4 persons convicted per 100,000 population). A decrease of $29 \%$ in 1995 that produced a relatively stable trend (oscillating between 2.0 and 2.3) from 1995 to 2001. A second decrease, of 18\%, that took place in 2002 and led to another stable trend (ranging from 1.7 and 1.8) until 2006. Finally, the 2006 rate of persons convicted for completed homicide per 100,000 population was $3 \%$ lower than the 1990 one, and the average annual decrease of that rate was $0.04 \%$ between 1990 and 2006. In particular, Hungary and Croatia showed 2006 rates that were respectively $0.05 \%$ and $1.6 \%$ lower than in 1990, while Bulgaria presented a 2006 rate that was $0.8 \%$ higher than the rate of 1990.

For the whole of Europe, the trend shows an increase of roughly 30\% between 1990-1991 and 1992-1994 (from 1.0 to 1.3 persons convicted per 100,000 population), followed by a decrease in 2005 that led to a relatively stable trend (oscillating from 1.1 to 0.9 ) from 1995 until the end of the series. The 2006 European rate was $6 \%$ higher than the rate of 1990, although the average annual percentage change suggests an annual decrease of $-0.7 \%$.

Assault

The standard definition of the European Sourcebook describes assault (considered as a synonym of bodily injury) as "inflicting bodily injury on another person with intent" (Aebi 
et al. 2010: 350-1). As a rule, figures include minor assault, aggravated assault, assault of a public servant, domestic violence, and attempts; but they exclude assault leading to death, threats, assault only causing pain, slapping, punching, and sexual assault. Nineteen countries -14 in Western Europe and five in Central and Eastern Europe (for details, see Table 1)- provided data on assault. Their trends are shown in Fig. 4.

After remaining stable from 1990 to 1992, the rate of persons convicted for assault in Western European countries increased by $8 \%$ in 1993, before decreasing by the same proportion in 1994-1995. The following year heralds the beginning of an upwards trend that implied an increase of $18 \%$ until 2002, followed by a more steady increase (19\% between 2002 and 2004) that led to an overall stable rate between 2004 and 2006. Thus, the 2006 rate of persons convicted for assault was $40 \%$ higher than the rate of 1990 and, between 1990 and 2006, there was an average annual increase of $2.3 \%$ of that rate. Only three countries (Austria, Greece and England and Wales) registered lower rates in 2006 than in 1990. Such rates were between 19 and 78\% lower in 2006 than in 1990. The other 11 countries (Belgium, Finland, France, Germany, Italy, Netherlands, Portugal, Sweden, Switzerland, Northern Ireland, and Scotland) registered increases, with rates for 2006 that were between $6 \%$ and $658 \%$ higher than the ones for 1990 .

In Central and Eastern European countries, the rate of persons convicted for assaults registered a relatively constant upwards trend from 1990 to 2004 (when the rate was $119 \%$ higher than in 1990) and a very slight decrease (4\%) in 2005-6, which suggests a stabilization of the trend by the end of the series. The 2006 rate of persons convicted for assault was $110 \%$ higher than the rate of 1990 , and the average annual increase of that rate was $4.9 \%$. The five countries included in the analysis (Bulgaria, Czech Republic, Hungary, Poland, and Slovenia) showed higher rates in 2006 than in 1990, with increases ranging from $14 \%$ to $251 \%$.

The overall European trend shows a constant upwards trend that led to a 2006 rate of persons convicted for assault per 100,000 population that was $56 \%$ higher than the 1990 rate. The average annual increase of that rate between 1990 and 2006 was $2.9 \%$.

Rape

The standard definition of the European Sourcebook describes rape as "sexual intercourse with a person against her/his will (per vaginam or other)" (Aebi et al. 2010: 354). As a rule, figures include penetration other than vaginal (e.g. buggery), violent intra-marital sexual intercourse, sexual intercourse without force with a helpless person, sexual intercourse with force with a minor, and attempts; but they exclude sexual intercourse with a minor without force and other forms of sexual assault. Figure 5 shows trends in persons convicted for rape, for which data are available for 23 countries. Among them, 14 are in Western Europe and 9 are in Central and Eastern Europe (for details, see Table 1).

In Western European countries, the rate of persons convicted for rape followed a curvilinear but overall slightly upwards trend between 1990 and 2006. The 2006 rate was $18 \%$ higher than the rate of 1990 , and the average annual increase of that rate was $0.9 \%$. Only three countries (Greece, Portugal, and Northern Ireland) showed 2006 rates that were between $12 \%$ and $77 \%$ lower than the 1990 ones. Austria presented the same rate in both years; while the other ten countries presented 2006 rape rates that were between $4 \%$ and $190 \%$ higher than the rates of 1990 .

Central and Eastern European countries started the series with relatively high rates of persons convicted for rape (3.0 per 100,000 population). This rate drop to 2.3 persons convicted in 1993 and followed afterwards a curvilinear but overall stable trend, which oscillated between 2.2 and 2.6 persons convicted per year. The 2006 rate was $21 \%$ lower 
than the rate of 1990, and the average annual decrease of that rate was $0.9 \%$. Indeed, six countries (Croatia, Czech Republic, Hungary, Latvia, Romania, and Russia) showed 2006 rates of persons convicted for rape that were between $26 \%$ and $57 \%$ lower than in 1990 ; while three countries (Bulgaria, Poland, and Slovenia) showed 2006 rates that were between $18 \%$ and $88 \%$ higher than in 1990 .

The overall European trend oscillated between 1.6 and 1.8 persons convicted for rape during the whole period -indeed the 2006 rate was only $1 \%$ higher than the rate of 1990 -, revealing an annual average increase of only $0.2 \%$, which can be considered as a synonym of stability.

\section{Robbery}

The standard definition of the European Sourcebook describes robbery as "stealing from a person with force or threat of force" (Aebi et al. 2010: 360). As a rule, figures include muggings (bag-snatchings), theft immediately followed by force or threat of force used to keep hold of the stolen goods, and attempts; but they exclude pick-pocketing, extortion, and blackmailing. Trends in persons convicted for robbery in 20 countries -12 in Western Europe and eight in Central and Eastern Europe (for details, see Table 1)- are presented in Fig. 6.

In the whole of Europe, the rate of persons convicted for robbery increased constantly between 1990 and 2006. The increase was much more pronounced in Central and Eastern Europe, where the average annual increase was $6.4 \%$, in such a way that the 2006 rate of persons convicted per 100,000 population was $200 \%$ higher than the 1990 rate. At the same time, in Western Europe, the average annual increase was $1.8 \%$, and the 2006 rate of persons convicted for robbery was $45 \%$ higher than the rate of 1990 . Out of the 20 European countries included in our analysis, only Northern Ireland and Scotland showed lower rates (39\% and 32\% respectively) in 2006 than in 1990. For the whole of Europe, the annual average increase of the rate of persons convicted for robbery between 1990 and 2006 was $3.6 \%$, and the 2006 rate was $94 \%$ higher than the rate of 1990 .

Theft

The standard definition of the European Sourcebook describes theft as "depriving a person or organisation of property without force with the intent to keep it" (Aebi et al. 2010: 361). As a rule, figures include minor theft, burglary, motor vehicle theft, theft of other items, and attempts; but they exclude embezzlement, robbery, and receiving or handling stolen goods. Figure 7 show trends in persons convicted for theft in 22 countries. Among them, 14 are in Western Europe and eight are in Central and Eastern Europe (for details, see Table 1).

In Western European countries, the rate of persons convicted for theft increased by about $12 \%$ at the beginning of the 1990s (1991-3) and decreased in a similar proportion between 1994 and 1995, keeping afterwards, until 1998, a level comparable to the one of 1990. The year 1999 heralds the beginning of a downwards trend that continued until the end of the series. Thus, the 2006 rate was $21 \%$ lower than the rate of 1990 , and the average annual decrease of that rate between 1990 and 2006 was $2.3 \%$.

Central and Eastern European countries experienced a steady upwards trend in the rate of persons convicted for theft from 1990 to 1999 (when the rate was 88\% than in 1990). Since 2000, that rate started decreasing -with exceptions in 2004 and 2005- until 2006. That year, however, the rate was still 63\% higher than in 1990, and its average annual increase between 1990 and 2006 was $2.3 \%$.

When Europe is considered as a whole, the rate of persons convicted for theft increased from 1990 to 1998 and have been decreasing since then. The 2006 rate was 
comparable to the one of $1990(+2 \%)$ and the average annual decrease of that rate from 1990 to 2006 was $0.6 \%$.

\section{Drug Offences}

The European Sourcebook does not provide a definition of drug offences. Instead, it indicates that such definition "is fairly uniform through international conventions" (Aebi et al. 2010: 371). In principle, figures include consumption, cultivation, production, sale, supplying, transportation, importation, exportation, and possession of large and small quantities of drugs, as well as the financing of drug operations. Trends in persons convicted for drug offences in 21 countries -12 in Western Europe and eight in Central and Eastern Europe (for details, see Table 1) - are presented in Fig. 8.

The rate of persons convicted for drug offences increased constantly in Europe between 1990 and 2006. The increase was much more pronounced in Central and Eastern Europe, where that rate was close to zero in 1990 and increased up to 30.6 per 100,000 population in 2006. This implies an average annual increase of 32\%, and a 2006 rate almost 4,500\% higher than the rate of 1990. At the same time, in Western Europe, the average annual increase of the rate of persons convicted for drug offences between 1990 and 2006 was $5.8 \%$, and the 2006 rate ( 60.5 persons per 100,000 population) was $186 \%$ higher than the rate of 1990 (21.1 persons per 100,000 population).

The 20 European countries included in our analysis showed higher rates of persons convicted for drug offences in 2006 than in 1990. The annual average increase of the European rate between 1990 and 2006 was $15.5 \%$, and the 2006 rate was $769 \%$ higher than the rate of 1990 .

\section{Discussion}

After presenting a brief summary of the trends shown in the previous figures, this section tries to find a plausible explanation to the evolution of convictions in Europe. In that context, trends are places in a wider historical perspective that takes into account the evolution of delinquency after World War II. The influence of reporting rates on recorded crime are also studied, and the analysis is complemented with an overview of the evolution of the composition of European prison populations. Finally, the main theoretical explanations of crime trends in industrialized countries -as well as those provided by researchers that have studied the crime drop in the United States and those who have suggested that such crime drop also affects Europe- are discussed, before proposing a multifactor model that fits the trends observed.

\section{Overview of the Trends in Persons Convicted in Europe}

After an increase in the early 1990s, the rate of persons convicted for theft has been decreasing in Europe. This decrease started in 1994 in Western Europe and in 2000 in Central in Eastern Europe. ${ }^{19}$ The situation is quite different for violent offences. The rate of persons convicted for robbery has been constantly increasing in Central and Eastern Europe

\footnotetext{
${ }^{19}$ Trends in persons convicted for other property offences are available for a few countries only, but the current downwards trend in theft is corroborated by the few available data on theft of motor vehicle, burglary, and domestic burglary.
} 
from 1990 to 2006; in Western Europe there has also been a general increase, interrupted only by two periods of relative stability between 1996 and 2002 and from 2004 to 2006. The situation is similar for the rate of persons convicted for assault, which also shows an upwards trend across Europe from 1990 to 2004. From 2004 to 2006, the trend in both regions of the continent seems stable. In the case of the rate of persons convicted for rape, Western Europe shows a slightly upwards trend from 1990 to 2006, while in Central and Eastern Europe the rate dropped in 1993 and remained overall stable until 2006. The rate of persons convicted for intentional homicide (including attempts) increased in both sides of the continent at the beginning of the 1990s. This increase -more pronounced in Central and Eastern Europe than in Western Europe- was followed, since 1996, by a period of relative stability. The latter lasted in Western Europe until the end of the series, while in Central and Eastern Europe there was a slight decrease in 2005-6. Trends in persons convicted for completed intentional homicide (i.e. without attempts) were only available for a few countries, but confirmed the increase at the beginning of the 1990s. In Western Europe, this increase was followed by a similar decrease in 1994-5 and a period of relative stability until the end of the series. In the three Central and Eastern European countries that provided data there was a first decrease in 1995 and a second one in 2002 followed in both cases by periods of relative stability. Finally, the rate of persons convicted for drug offences has followed a steady upwards trend from 1990 to 2006 in the whole of Europe.

\section{Are We Living in a More Intolerant Society? Reporting Rates Revisited}

An argument often advanced to explain the rise of non-lethal violent offences is that contemporary developed societies have become more sensitive to violence. As a consequence, victims are more willing to report violent offences and police forces are more willing to record them. This idea can be traced back, for example, to Garland (1996) when he affirms that "The increases in recorded crime have also had the practical effect of massively increasing the 'throughput' of the criminal justice process, with steep increases in crimes reported to the police, prosecutions brought, cases tried and offenders punished" (Garland 1996: 455). Later, that increased sensitivity has been taken for granted in statements such as the following: "In all eight countries [Australia, Canada, England and Wales, Netherlands, Scotland, Sweden, Switzerland, United States], including the United States (see, e.g., Blumstein and Wallman 2000), reporting and recording practices changed in the final decades of the twentieth century, reflecting reduced tolerance of violence generally and domestic and sexual violence in particular" (Blumstein et al. 2005: 350). In the same perspective, Mucchielli (2010) considers that "our society no longer tolerates violence, no longer considers it legitimate or meaningful. Our threshold of tolerance is lower and lower [...]. The result is that interpersonal violence that is not new is now denounced" (Mucchielli 2010: 813).

Much of the appeal of this hypothesis comes probably from the fact that it is related to the everlasting idea that past times were always better. From a scientific point, it is therefore indispensable to test it with empirical data. Such data can be found in the International Crime Victim Survey (ICVS), which has measured the reporting rates (i.e. percentage of the offences suffered during the previous 5 years that were reported to the police) for assault including threats- and robbery from 1998 to 2004.

Among Central and Eastern European countries, only Poland and Estonia dispose of victimization data -based on four waves of the ICVS (van Dijk et al. 2007)- since 1992 and 1993 respectively. These data show a moderate increase in Estonia -from $22 \%$ to $26 \%$ - and 
a medium increase in Poland -from $25 \%$ to $38 \%$ - of the percentage of assault victimizations reported to the police from 1992-3 to 2004. Regarding robbery, a less pronounced increase was observed in Poland $-31 \%$ in 1992 and $38 \%$ in 2004-, while the reporting rates remained stable in Estonia $-38 \%$ in 1993 and 39\% 2004. The increases observed are associated with an amelioration of police confidence -measured in terms of the percentage of respondents that think that police are doing a good job in controlling crime in the local area- in both countries during that period (van Dijk et al. 2007: 142).

In Western Europe, the hypothesis of an increase in reporting rates can be tested more properly as nine countries (Belgium, England and Wales, Finland, France, the Netherlands, Northern Ireland, Scotland, Sweden, and Switzerland) participated in at least four of the five waves of the ICVS and provided such data. ${ }^{20}$ Trends in reporting rates for assaults (including threats) and robbery are presented in Fig. 9 using, as in the rest of this article, the geometric mean as a measure of central tendency. ${ }^{21}$

As can be seen in Fig. 9 , the ICVS data provide no empirical support for the hypothesis of a reduced tolerance of violence in Western European societies between 1988 and 2004. Indeed, the percentage of robberies reported to the police remained overall stable - the $13 \%$ increase between 1992 and 2000 is counterbalanced by a similar decrease in 2004- during that period of time, and the same is true for assaults and threats.

This does not mean, of course, that the perception of crime by the society has not changed since the 1970s. Garland (2001) has described many of the transformations in such perception in the British and American societies, and it seems reasonable to think that some of these transformations concerned also other industrialized societies. It is therefore plausible to think that nowadays interpersonal violence is less tolerated in Western European societies than one generation ago and that, as a consequence, some violent offences are more easily reported to the police and more easily recorded by them too. However, it does not seem realistic to explain only through this reduced tolerance of violence the trends observed in violent offences in Western Europe. As the increase in such offences according to police and court statistics is practically linear since the beginning of the 1990 s until the mid 2000s, applying that explanation implies accepting that we are living in societies that year after year become less and less tolerant, in such a way that one wonders which would be the upper limit of that intolerance. For example, threats -that are a less serious behaviour than a physical assault or a robbery- should be reported more frequently to the police, but the ICVS question on reporting rates of assault includes threats, and the results presented in Fig. 9 show that the reporting rates remained stable.

Indeed, the limited increase in the reporting rates of violent offences in Central and Eastern European countries -where the breakup of the Soviet Union produced different, but not less dramatic, changes in the perception of crime by the society than the ones described by Garland (2001)-, and the stability of such rates in Western European countries (Fig. 9), mean that the constant upwards trend in violent offences shown by police and conviction statistics from the early 1990 s to the mid 2000s is not a social artefact.

\footnotetext{
${ }^{20}$ England and Wales, Finland and the Netherlands participated in the five waves of the ICVS. France, Northern Ireland, Scotland and Switzerland did not participate in the second wave, while Belgium did not participate in the third wave. In these cases, the missing value was calculated using linear interpolation. Sweden did not participate in the first wave and its value for that year was extrapolated by repeating the one provided for the second wave. It can be seen that the logic for these interpolations and the extrapolation is the same applied for the missing values in conviction statistics.

21 The authors wish to thank John van Kesteren, who provided them with the figures required to calculate these rates (van Kesteren, personal communication, October 14, 2009).
} 


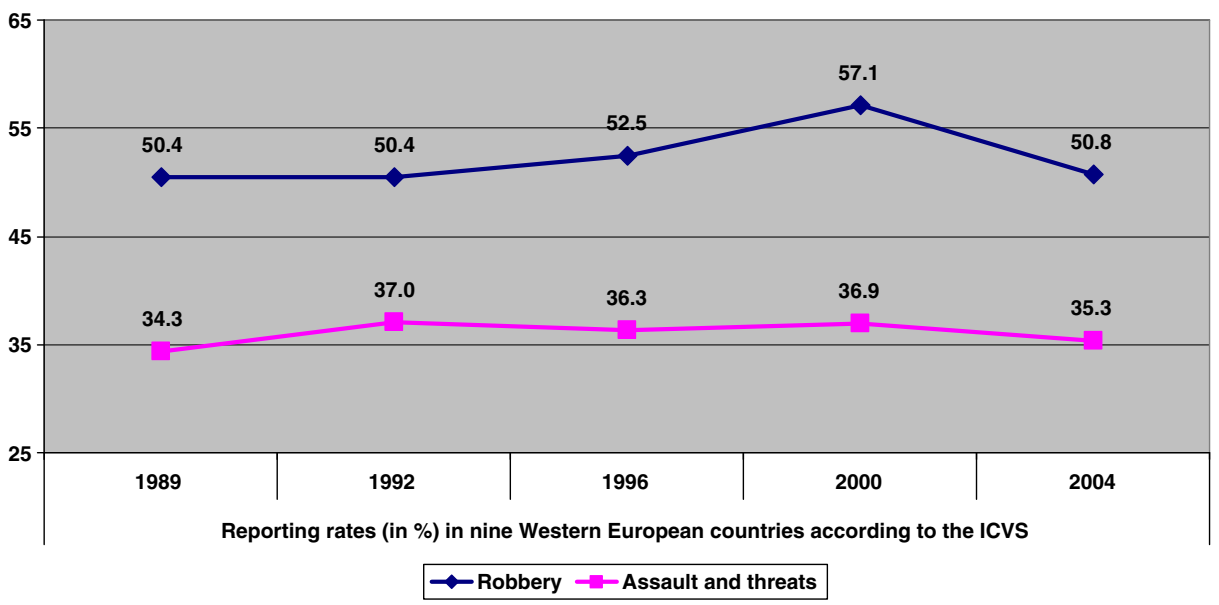

Fig. 9 Reporting rates (in percent) for robbery and assault (including threats) in nine Western European countries between 1988 and 2004, according to the ICVS (Geometric means)

\section{Violent Offenders and Drug Offenders in European Prisons}

If reporting rates of violent offences are not increasing, the question is whether the increase in the number of convictions for non-lethal violent offences reflects a real change in criminality in Europe. In that perspective, the evolution of the composition of European prison populations can provide an alternative measure of such change.

In this respect, the case of France is paradigmatic. According to Tournier (2011), on 1 January 1971, France had 29,540 persons held in penal institutions, of which $50 \%$ were serving a sentence for common theft and $20 \%$ for violent offences (homicides, assaults and sexual aggressions). Thirty years later, on 1 January 2011, the country had 68,561 detainees, but only $7 \%$ were serving a sentence for common theft and $47 \%$ for violent offences (Tournier 2011). This radical overturn of the distribution of the prison population suggests that there has been a genuine change in the types of crimes sanctioned in France. Moreover, the case of France is not an exception. According to the latest available data on the composition of European prison populations, on 1st September 2009, approximately $44 \%$ of the persons imprisoned in Europe were serving sentences for violent offences (homicide, assault and battery, robbery, rape and other sexual offences), 19\% were in detention for drug offences, $20 \%$ for theft, $5 \%$ for economic and financial offences, and the rest for other types of offences (Aebi and Delgrande 2011: 70). It must be emphasized here that we are not facing only a change in the proportion of persons imprisoned for violent offences -that could be explained by an enhanced use of alternatives to imprisonment for property offenders-, but also an increase in the rates per 100,000 population of persons convicted for violent offences as well as police recorded violent offences, until the mid-2000s.

The fact that drug offenders and violent offenders represent the majority of the European prisoners corroborates indirectly the trends observed in this article. While, in the post-war years, property offences played a major role in the composition of European criminality that was clearly highlighted by the so-called critical criminology in the 1970s (see, for example, Taylor et al. 1973)-, in the twenry-first century, their weight is far less important. As a consequence, the rise of violent offences in Europe does not seem to be an illusion, a moral panic, or the consequence of unfounded fears, but a social fact. 
Crime Trends in Europe since 1950

Longitudinal analyses such as the one presented here are usually criticized for not taking into account that the trends observed during a limited period of time may be influenced by the previous evolution of the phenomenon under observation. As a consequence, we tried to find reliable data on the evolution of crime in Europe before 1990. That task turned out to be impossible for Central and Western European countries due to the selective way in which criminal statistics were produced under the communist regimes that ruled those nations. The same is true for Spain and Portugal, which spent several decades of the twentieth century under dictatorial regimes. However, for other Western European countries, data are available and have already been analyzed. Thus, studying trends from 1950 to 1988 in England and Wales, France, the Federal Republic of Germany, the Netherlands and Sweden, van Dijk (1991: 31) concluded that "Crime has gone up from 1955 onwards across Western Europe. In Sweden the upwards trend started immediately after the war". The data collected by van Dijk (1991) shows that by the mid 1980s, crime trends were roughly between three and five times higher than in 1950. However, "Between 1985 and 1986 registered crime in France, England and Wales, the Federal Republic of Germany (FRG) and the Netherlands seems to have reached a ceiling [...]" (van Dijk 1991: 29).

The upwards trend in police recorded crime in Western Europe since the mid 1950s is similar to the one observed in the United States after World War II. As it is well known, Cohen and Felson (1979) developed the Routine activity approach to explain that evolution, showing that the major shift in routine activities away from home, experienced in the United States after the war, had increased the probability that motivated offenders would converge in space and time with suitable targets in the absence of capable guardians, hence increasing crime rates. The same explanation can be applied to Western Europe, where similar changes took place in terms of female labour force participation, the multiplication of single-adult households, and the burgeoning of lightweight but valuable goods. ${ }^{22}$ Thus, according to van Dijk (2006b), "Opportunities for crime have gone up together with increasing affluence since the post-war economic boom. This has resulted in epidemics in volume crime across the Western world. The finding that crime started to boom latest in Ireland is in line with this interpretation since economic growth came relatively late to that country" (van Dijk 2006b: 17). However, by the mid 1980s, the increase in crime rates seemed to have reached its upper limit. With the exception of violent offences in England and Wales and the Netherlands, crime rates were stable -or even going down in France- between 1985 and 1988 (van Dijk 1991). Two years later, the break up of the Soviet Union introduced a major socio-political and economic change that, according to the data presented here, seems to have had a major impact on delinquency.

A similar evolution was found in an analysis of trends in homicide since 1970 in 15 Western European countries according to the World Health Organization health statistics. Those data show that homicide increased by steps from 1970 to the mid-1980s and decreased slightly during the second half of the 1980s, before increasing again to reach a peak at the beginning of the 1990s (Aebi and Linde in press). In that context, the main challenge is to find a plausible theoretical explanation to the changing trends observed since 1990.

\footnotetext{
${ }^{22}$ Mobile phones provide a relatively recent example of the influence of lightweight valuable goods on crime rates. For example, in England and Wales, the number of police recorded phone thefts doubled between $1998 / 1999$ and $2000 / 2001$, and it was estimated that $28 \%$ of the robberies in $2000 / 2001$ involved a phone, a proportion that represents an increase of $8 \%$ in such robberies in two years (Harrington and Mayhew 2001).
} 
Theoretical Explanations of Crime Trends from a Macro-social Perspective

LaFree (1999) classifies the predominant explanations for post-war crime trends in those based on exogenous causes and those based on public policy causes. ${ }^{23}$ The main exogenous causes are economic stress, political legitimacy, family disorganization, the proportion of young people in the general population, the evolution of drug markets, and changes in routine activities. The main public policy causes are related to police initiatives as well as to the evolution of incarceration rates, education and welfare (LaFree 1999). Some of these explanations have been subsumed in general crime theories. For example, even if "specific arguments vary enormously, most theorists assume that economic stress undermines legitimacy and weakens social bonds"; as a consequence it is theorized that increased levels of economic stress will lead to an increase in crime rates (LaFree 1999: 148). This argument can be found in a direct or indirect form in theories of strain, social disorganization, social control, conflict, violent subcultures, and criminal motivation. The same is true for family disorganization because family has always been considered as the first socialization agent, as an agent of informal social control -that can supervise and regulate the activities of its members- and as a protective factor for family members (LaFree 1999: 151).

The problem -as we have explained it with more detail elsewhere (Aebi and Linde 2010) - is that almost none of these theories can explain why the previous causes can lead to a decrease in property offences and, at the same time, to an increase in violent offences and drug offences. Indeed, the fact that there are no homogeneous trends in the evolution of crime in Europe falsifies ab initio the reasons that has been proposed to explain the crime drop in the United States as well as the explanations that can be drawn from most criminological theories. All the theoretical constructions take as a premise that the majority of the offences evolve in the same way, as it was the case in the United States, where both property and violent offences started decreasing in the early 1990s. Thus, leaving aside the fact that a few of the explanations of the American crime drop must be discarded because they cannot be extrapolated to Europe -for example, some authors (Blumstein and Rosenfeld 1998; Levitt 2004) suggested that the evolution of the crack epidemic in the United States parallels the evolution of American crime rates, but such an epidemic did not exist in Europe-, all those explanations cannot be taken into account because it is impossible to justify why increasing imprisonment (Levitt 1996), the legalisation of abortion (Donohue and Levitt 2001), an increase in the number of police officers (Levitt 2004 ) or changes in demographics and economic opportunities, ${ }^{24}$ would produce an increase in violent offences and a decrease in property offences.

Only opportunity-based theories, which are extremely flexible, allow explanations that could fit these heterogeneous trends. At the same time, the flexibility of opportunity-based theories is one of its major weaknesses, as they can be extremely difficult to falsify. That is indeed a common problem of macro-sociological theories, which are seldom falsifiable (Chamlin and Cochran 2007; Lenski 1988). In that context, before proposing a multifactor model inspired by opportunity-based theories, we will review the explanations that have been proposed to explain the recent evolution of crime trends in Europe.

\footnotetext{
${ }^{23}$ Although LaFree (1999) refers to the explanations given for postwar crime trends in the United States, his classification can be extrapolated to the explanations of crime trends in Western Europe. Not only did both regions undergo a similar evolution both in socioeconomic and political terms after World War II, but European criminologists have not proposed alternative explanations for the trends observed in the Old Continent.

${ }^{24}$ For these and other explanations of the crime drop in the United States, see Blumstein and Wallman (2000, 2006) and Zimring (2007).
} 
The Crime Drop: Proof by Assertion?

In the previous section, we have mentioned the main explanations that have been given for the crime drop in the United States of America. In that country, crime started decreasing at the beginning of the 1990s, an evolution that had not been anticipated by any researcher. By the end of the 2000s, some authors started suggesting that such drop was common to most industrialized countries. For example, according to Rosenfeld and Messner (2009: 445), "[...] the USA and European crime declines occurred in tandem [...]", and according to Farrell et al. (2011: 147), "Major crime drops were experienced in the United States and most other industrialized countries for a decade from the early to mid-1990s".

Looking at the trends shown in this article, and the similar trends found by Aebi and Linde (2010) on the basis of police statistics, one wonders what is the empirical evidence behind such assertions. Usually, the main source invoked to support the hypothesis of a general crime drop in Europe is the analysis conducted by van Dijk et al. (2007) of the fifth International Crime Victim Survey (ICVS), which included a comparison with the four previous waves of that survey. Thus, according to Farrell et al. (2011: 148), "With variation by country and crime type, there were significant declines in crime across the European countries for which reliable comparison could be made using the International Crime Victim Survey (van Dijk 2006a, b; van Dijk et al. 2007)". Rosenfeld and Messner (2009) also refer to those analyses: "Drawing upon data from the International Crime Victim Survey (ICVS) for those 15 nations that allow for comparisons over 10-15 year periods, van Dijk et al. (2007: 16) observe that, similar to the general pattern in the USA, average victimization rates peaked in the mid-1990s and steadily declined thereafter. These falling trends were especially appreciable for property crimes such as burglary and vehicle-related offences" (Rosenfeld and Messner 2009: 446).

The main problem with the reasoning presented by Rosenfeld and Messner (2009) is that the United States are included in the 15 nations for which van Dijk et al. (2007: 100) conducted that particular trend analysis. As a consequence, the overall trend shown by victimization rates is influenced by the presence of that country. The second problem is that there are no references or only veiled references to the evolution of violent offences. Going back to the original source, one can read that "Personal thefts show the by now familiar curve-linear trend with an all time peak in 1991. Threats and assaults do not fully conform to this pattern: rates of victimisation peaked around 1999. Sexual offences and robberies show no distinct trends but seem to be decreasing slowly" (van Dijk et al. 2007: 101). Apart from the already mentioned problem of the presence of the United States among the 15 countries included in the analysis, one can see there are "no distinct trends" for sexual offences and robbery and that the peak for assault and offences was registered in 1999, which means that there is only one measure -the ICVS conducted in 2005to support the idea of a drop in those offences. Moreover, when the analysis is restricted to the three European Union countries that participated in the five ICVS waves, the situation is uncertain: "The picture of contact crimes is more varied. Violent crime has remained stable in the Netherlands and has increased in England \& Wales from 1988 to 2000 and remained stable since then. Contact crimes have dropped below the level of 1988 in Finland" (van Dijk et al. 2007: 102). In addition, in a more detailed analysis of trends in contact crimes in Europe from 1988 to 2005, van Dijk (2008) concluded that: "The ICVS data set indicates significant decreases in contact crimes in Estonia, Poland, Finland, and France. In the other [five] countries [Belgium, Netherlands, Sweden, Switzerland, and the United Kingdom], levels of robberies, threats or assaults, and sexual offences have gone up between 1988 and 1992 and thereafter 
remained more or less stable" (van Dijk 2008: 127). ${ }^{25}$ Indeed, it is only when overall rates -i.e. including all offences- are taken into account (see, for example, the rates presented by Tonry 2010) that a drop can be seen, and this is because property offences, which are much more common than violent offences, have a predominant influence on such aggregated rates.

Furthermore, the evolution of violent offences is usually left aside by the researchers that have conducted empirical research on the evolution of crime trends in Europe. For example, Rosenfeld and Messner (2009) analyse the evolution of police recorded burglaries in the United States and in nine European countries from 1993 to 2006, Farrell et al. (2011) study the evolution of vehicle theft in England and Wales from 1991 to 2006 and in Australia from 1997 to 2007, and van Dijk (2010) concentrates himself in the evolution of burglary, according to the ICVS, in five European countries from 1980 to 2008. In the three cases, the results of their analyses coincide with the trends shown in this article for property offences.

However, when providing explanations for the trends observed in their analyses, all these authors assume that there is a general crime drop in industrialized countries. Thus, Rosenfeld and Messner (2009: 147) "suggest that the USA and European crime declines occurred in tandem because they were both brought about by upturns in the economy"; van Dijk (2010) considers that the increase in security measures in Europe may explain such decrease -an evolution that he had already foreseen 16 years before (van Dijk 1994)-; and Farrell et al. (2011) suggest that the drop in car theft is mainly due to security measures -in particular, electronic immobilizers and central locking- and that the reductions in car theft have disrupted the routine activities that facilitate other crimes. As a consequence, "reduced car theft may have induced drops in other crime including violence" (Farrell et al. 2011: 147).

Two striking features - one explicit and one tacit- must be underlined here. The first one is the overgeneralization of the crime drop observed in property offences to the rest of the offences, and the second one is the absence of references to the relevant European literature on crime trends.

The overgeneralization of the crime drop reminds us of the logical fallacy known as proof by assertion. It consists of repeating an argument despite its eventual inconsistencies until it is commonly accepted. In this case, there is no clear evidence of a drop in violent offences in Europe, but some researchers seem to accept it as a fact. In order to justify it, they keep quoting the same reference (the appeal to authority fallacy) even if a detailed analysis of that reference shows its inconsistencies.

The absence of references to the European literature on crime trends is probably a reflection of the way in which the world of quotations works in social sciences. Three issues of the European Journal on Criminal Policy and Research were devoted to the analyses of crime trends in Europe from 1990 to 1996 (issue 8/1 in 2000) and from 1996 to 2000 (issues 10/2-3 in 2004), but none of the articles included in those issues are quoted in the articles by Rosenfeld and Messner (2009) and by Farrell et al. (2011). ${ }^{26}$ In particular, Farrell et al. (2011) arrive to the conclusion that "Routine activity theory provided what is probably the most convincing explanation, against expectations, for the coincidence between increasing crime levels and

\footnotetext{
${ }^{25}$ The trends found by van Dijk (2008: 127) are similar to the ones found by Aebi and Linde (2010), even if the latter combined all Western European countries in a single cluster and studied assaults and robberies separately, while van Dijk (2008) combined three different types of victimizations in a single cluster (assaults and threats, robberies, and sexual offences) and analysed trends in each country. In particular, the analysis of van Dijk (2008: 127) shows that in six out of eight Western European countries there was no drop in violent victimizations.

${ }^{26}$ This critique is not addressed to the short articles published in Criminology in Europe, the Newsletter of the European Society of Criminology (Tonry 2010; van Dijk 2010), which is not a peer-reviewed journal, but to the ones published in the The British Journal of Sociology (Rosenfeld and Messner 2009) and the Journal of Research in Crime and Delinquency (Farrell et al. 2011), which are two of the most prestigious peerreviewed journals in the field of social sciences.
} 
increasing levels of wealth and welfare in the second half of the twentieth century (Cohen and Felson 1979). It is odd that it has been rarely drawn on as a starting point for looking at the equally unexpected falls in crime since the early 1990s." However, opportunity-based theories were used by Killias and Aebi (2000) to explain the evolution of crime trends in Europe from 1990 to 1996, by Aebi (2004a) to explain such trends from 1990 to 2000 and, more recently and therefore without the possibility of being quoted-, by Aebi and Linde (2010) to explain European crime trends from 1990 to $2007 .{ }^{27}$ A simple internet search in a non-scientific Web search engine such as Google with the basic keywords "crime - trends - Europe" shows, as the initial entry (under the heading "Scholarly articles for crime trends Europe"), the three articles mentioned above. The reasons for which the authors and the reviewers of the articles criticized here decide to ignore those references are unknown.

\section{A Multifactor Explanation of Crime Trends in Europe}

After having shown that the main theoretical explanations of crime trends in industrialized countries cannot be applied to the recent evolution of delinquency in Europe, we will present in this section an alternative explanation based on a multifactor model inspired by opportunity-based theories. Our explanation is divided in two chapters. The first one is devoted to explain trends in Western Europe and the second one to explain trends in Central and Eastern Europe. The reason for that subdivision is that the general situation -in economical, political and social terms- was completely different at the beginning of the 1990s in those two regions of Europe. However, in the conclusion of this article, we will highlight some features that are common to both regions.

\section{Explaining Trends in Conviction Statistics in Western Europe}

Even if the time period and the countries and offences included do not overlap completely, the trends in conviction statistics in Western Europe shown here are very similar to the ones found in an analysis of the evolution of police recorded offences in Western Europe from 1990 to 2007 (Aebi and Linde 2010). A first difference between both studies is that the present analysis of conviction statistics includes data on Norway and Portugal, two countries that were not covered in the analysis of police statistics (Aebi and Linde 2010), which, on the other hand, included police data on Denmark and Ireland, two countries that are not covered here. A second difference is that the analysis of police statistics covered one more year (2007) than this analysis of conviction statistics. The third difference is that the present study includes trends in rape, which were only covered in a footnote in the research on police statistics, which, in contrast, included trends in domestic burglary and motor vehicle theft that are not covered here. Finally, the analysis of police statistics included also a comparison with the five waves of the ICVS, covering the period 1988-2004, which showed remarkable similarities between the evolution of both crime measures (Aebi and Linde 2010).

Summarizing these findings one can say that, in Western Europe, conviction statistics, police statistics and victimization surveys show a general increase of delinquency at the beginning of the 1990s. Drug offences continued to increase until the end of the period under study. Violent offences such as assault, robbery and rape also continued to increase, though the first two ones seem to have reached their upper limit by 2003-2004 and are relatively stable -or even slightly decreasing in the case of robbery- since then. The main differences comes from the fact that,

${ }^{27}$ In the three cases, opportunity-based theories were used to explain the decrease in property offences as well as the increase in violent offences and drug offences. 
according to police statistics, homicide has been decreasing since 1992-1994, while conviction statistics show a stable trend, and that the increase in rape is far more pronounced according to police statistics than according to conviction statistics.

These similarities imply that the multifactor model -inspired by opportunity-based theories such as the routine activities approach (Cohen and Felson 1979; Felson and Boba 2010)- proposed to explain trends in police statistics and victimization surveys (Aebi and Linde 2010) also fits the trends in conviction statistics shown in this article. According to that model, the increase of property offences in the early $1990 \mathrm{~s}$ is related to the consequences of the political and socioeconomic changes that took place at that moment in Europe. The collapse of the Soviet Union introduced a substantial modification of crime opportunities, leading to the development of a black market in Central and Eastern Europe that was supplied, at least partially, by organized gangs operating in Western Europe, which took advantage of the new paths of transportation for illegal goods and commodities across Europe. The subsequent decrease of property offences seems related to the saturation of that black market, the reinforcement of police measures against transnational crime at the borders of the EU, the improvement of the socioeconomic situation in many Central and Eastern European countries, the improvement of security measures in Western European households, and the substantial increase in private security in most Western European countries (for details and references, see Aebi and Linde 2010).

The increase in most violent offences seems related to a transformation in the lifestyle of European youths and changes in their demographics. The distribution of the spare time of the younger generations has been mainly influenced by the development of the Internet. "Youths who have unlimited access to the internet spend more time at home -and are more exposed to the risk of engaging in computer related offences, which have been increasing constantly-, while those who have a limited access to the Web spend more time in the streets and are differentially exposed to the risk of engaging in conventional delinquency. However, as the increase in security measures and private security has reduced the opportunities to commit property crimes, such risk exposition should have an influence mainly on violent and drug related offences. In that context, among youths who have limited access to the Internet, there is an overrepresentation of those with a low socioeconomic status and, among the latter, there is also an overrepresentation of ethnic minorities. This is probably one of the factors - combined with many others- explaining their differential involvement in delinquency according to official statistics and selfreported delinquency studies. Moreover, the number of youths who are second-generation ethnic minorities have increased in Europe during the last decades. In that perspective, research suggests that their presence is related to the recent development of European street gangs. Members of these gangs present high rates of violent offending, in particular group fighting. Also, some street gangs are involved in drug trafficking, which is also related to the commission of violent offences. Finally, research shows an increase in the percentage of youths engaged in heavy episodic drinking (binge drinking), and has also shown that among these youths there is a high prevalence of violent offending. Soft drug use has also increased among adolescents during the most part of the period studied, although it seems to have started decreasing lately" (Aebi and Linde 2010: 273). ${ }^{28}$

\footnotetext{
${ }^{28}$ Regarding the presence of second-generation ethnic minorities in Europe, see Weerman and Decker (2005). For the increase of security measures in Western Europe, see Lamon (2002) and van Dijk et al. (2007). Concerning the rise of private security companies and employees in the EU, see de Waard (1999). For the increase of the engagement of young people in binge drinking, see Hibell et al. (2009). Regarding the involvement of European youth gangs in violence and drug trafficking, see Klein et al. (2006).
} 
The fact that intentional homicide did not follow the same trend as the rest of violent offences could be related to the relatively low and stable rate of household gun ownership (Killias et al. 2001), the absence of major social conflicts, and the quality of health services in Western Europe. In particular, the low availability of guns and the improvements in the health care system imply that persons that could have been victims of homicide have become victims of assault.

In that perspective, three main hypotheses can be proposed for the divergence between police statistics, which show that homicide is decreasing (Aebi and Linde 2010), and conviction statistics, which present a stable trend. ${ }^{29}$ Such discrepancy could be due to a change in the ratio of offences to perpetrators. If the proportion of homicides committed in group is increasing, then the number of homicides can decrease while the number of persons convicted remains stable. The same pattern could be produced by recent improvements in detection and evidence gathering techniques -made possible through scientific and technological developments- that can be responsible for an increase in the proportion of cases solved by the police with sufficient evidence to lead to a criminal conviction. Finally, a rise of the proportion of domestic murders, which are easily solved by the police because the author is already known, could also produce the divergent trends observed in police and conviction statistics.

The available data do not allow testing in a proper way for those three hypotheses. However, the case of domestic murders merits particular attention. On the one hand, they constitute a particular constellation of murder that could have been evolving in a different way than the rest of the intentional homicides. On the other hand, one must take into account that domestic violence has become one of the criminal policy priorities in many European countries (see for example Graham-Kevan 2007). For example, in Spain -a country not included in our analysis- a law of $2004^{30}$ modified the criminal code in such a way that every type of aggression against a partner or former partner must be qualified as an offence, even if the same behaviour would be qualified as a misdemeanour if the victim was not related to the offender. In an analogous way, the rate of convictions for intentional homicide including attempts could be affected by the fact that some cases that could have been qualified previously as serious assaults are now being considered as attempted homicides. As domestic murders may represent up to one third of the total homicides committed in some Western European countries (Geneva Declaration Secretariat 2008: 5), this issue cannot be overlooked. ${ }^{31}$ In the same perspective, as there are no longitudinal data available on the trends in convictions for domestic violence since 1990, it is impossible to measure their influence on the number of persons convicted for assault.

\section{Explaining Trends in Conviction Statistics in Central and Eastern Europe}

The trends in conviction statistics in Central and Eastern Europe shown here are very similar to the ones found in a study of trends in police recorded offences and WHO health

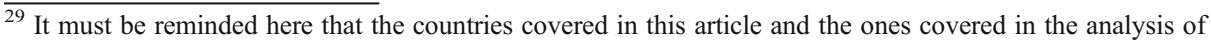
police statistics (Aebi and Linde 2010) are not exactly the same, and that the counting units used in both articles are different because police statistics refer to offences known to the police and conviction statistics refer to persons convicted. These factors may also play a role in the divergences observed between the two studies regarding trends in homicide.

${ }^{30}$ Organic law 1/2004 on Integral protection measures against gender violence.

${ }^{31}$ Reliable figures on the number of women victims of homicide (i.e. femicide) perpetrated by partners or expartners are not easy to find. For the year 2006, it is possible to combine the figures on femicide collected by Nectoux (2010) with the figures on completed homicide included in the European Sourcebook. This combination shows that, in Western European countries, femicides represent between $15 \%$ and $30 \%$ of all completed homicides.
} 
statistics in 12 Central and Eastern European countries between 1990 and 2007 (Aebi and Linde in press). The main differences are that the analysis of police statistics included Lithuania -which is not covered here-, extended the time frame until the year 2007 instead of 2006 in this article-, and excluded rape, which is covered here. The convergence of both studies increases the reliability of their findings and implies that the explanations provided for the evolution of police recorded offences can also be applied to the trends observed in conviction statistics.

The general increase in all types of police recorded offences at the beginning of the 1990s have been explained by Aebi (2004b) and Gruszczynska (2004) applying mainly the routine activities approach (Cohen and Felson 1979; Felson and Boba 2010) and pointing out that social changes increase criminal opportunities. The collapse of the Soviet Union led to the development of a market economy - that multiplied the number of consumer goods which are suitable targets for theft - and was accompanied by a social fracture between those with power or influence and the rest of the population, creating thus the setting for an increase of property offences (Aebi 2004b). However, since 2000, the rate of persons convicted for theft in Central and Eastern Europe has been following a downwards trend. According to Gruszczynska (2004), the fall of property offences is related to the multiplication of private security companies and household security measures, which occupied the role vacated by the criminal justice system, whose police forces and public prosecutors were not properly prepared to react to the rise of criminality in the early 1990s. This downwards trend seems to reflect also an improvement of the socioeconomic situation in most Central and Eastern European countries, especially those that joined the EU, which experienced a decrease in their unemployment rates (Eurostat 2011). It could also be partially artificial because, as we have seen before, in some Central and Eastern European countries, the threshold to qualify theft of a small value as an offence was raised between 1995 and 2002 and, as a consequence, some thefts that were previously recorded as offences are now recorded as misdemeanours and therefore are not included in the statistics collected in the European Sourcebook. Finally, taking into account that rates cannot continue to rise endlessly, the drop in property offences as well as in homicides since the mid-1990s could also be due, at least partially, to the phenomenon known in statistics as regression towards the mean. The increase in persons convicted for theft and homicide in the early 1990s was so extreme that it has logically been followed by a decrease (Aebi and Linde in press).

In that context, Shelley (2002, with references) considers that the increase in violent offences during the 1990s in Russia is also a consequence of the transition. The latter was accompanied by an important growth of unemployment, a collapse of the social safety net, the bankruptcy of unofficial financial entities with the consequent loss of the savings of many citizens, the rise of youth crime, and the development of organized crime, enhanced by the corruption of government officials. In particular, Shelley (2002) considers that the rise of mortality in Russia is linked to the increased availability of weapons -whose trade was on the hands of organized crime and former militaries-, the killings related to organized crime, banditry, the division of the territory of major cities among crime groups, and the deterioration of the health care system that implied -contrary to what happened in Western Europe- that persons that could have been victims of assault became victims of homicide. Most of these reasons apply also to the rise of violent offences in the rest of Central and Eastern Europe.

At the same time, the opening of the European borders facilitated the distribution of drugs and led to struggles between the criminal organizations that tried to take control of the illegal drug market. The increased availability of drugs was correlated with a major increase in alcohol 
consumption and drug use in Central and Eastern Europe (EMCDDA 2008; Hibell et al. 2009; Pridemore 2002). Thus, the upwards trend in persons convicted for drug offences is linked to a real increase in drug consumption. However, as we have already mentioned, drug offences were at an extremely low level in 1990. Such level of official consumption and trafficking of drugs reflects the tendency of former communist countries to deny the presence of drug abuse in their territories. In fact, it was only just before the breakup of the Soviet Union that the Soviet government admitted that addiction to opiates and drugs other than alcohol existed in the country (Schaeffer Conroy 1990). This implies that the increase in persons convicted for drug offences in Central and Eastern Europe is also clearly correlated with a major change in drug policy.

\section{Conclusion}

In this article, we have traced the history of conviction statistics, we have summarized the unending debate on their validity and reliability, and we have used such statistics to measure crime trends in Europe from 1990 to 2006.

In particular, we have seen that conviction statistics were the first official statistics available in Europe. They started to be published during the first half of the nineteenth century and, by 1832, de Candolle had already identified their main weaknesses as measures of crime, as well as the problems involved in their use for cross-national comparisons of crime levels. During the following one hundred years, the development of police statistics led to a debate about which of these two official statistics would be the most appropriate indicator of crime rates. The International Institute of Statistics preferred conviction statistics but, in the United States, a majority of researchers and practitioners arrived at the conclusion that police statistics were more valid than conviction statistics because they were closer to the original offence than conviction statistics. As a consequence, in 1930, the United States chose police statistics to develop the UCR, which became immediately the main measure for the analysis of crime rates in that country and, as time went by, for the analysis of crime trends too. The fact that conviction statistics are more reliable than police statistics -because different judges confronted with the same case should arrive to the same decision-did not play a role in a debate whose goal was to find a measure that was close to the total number of offences committed. A few years later, in 1954, Interpol started publishing international police statistics. As a result, Interpol's data collection and WHO health statistics became the main databases for comparative criminologists, while conviction statistics -that were barely available at the international level until the 1970s, when the United Nations included them in the UNCTS- continued, until today, to be seldom used for comparative purposes. In that context, the convergence between the trends in conviction statistics found in this article and the trends shown in analogous analyses of police and victimization data suggest that conviction statistics can be used as a relatively valid indicator of crime trends in Europe.

Certainly, some of the validity problems of conviction statistics are inherent to them and therefore cannot be solved. Nevertheless, from a longitudinal perspective, we have seen that the reliability of time series can be improved through a careful analysis of changes in legal definitions and recording practices. These factors were taken into account when checking the available European data on conviction statistics, and they led us to focus our study on convictions for six offences for which reliable data were available in up to 26 European countries.

The results of our analyses of trends in persons convicted from 1990 to 2006 show two periods -at the beginning and at the end of the series- in which similarities can be found 
between Western Europe and Central and Eastern Europe. In the early 1990s, there was a general increase in the rates of persons convicted for almost all of the offences studied. For most of these offences, the trends diverged in the following years, with Central and Eastern Europe registering in most cases -with rape as an exception- higher increases than Western Europe. However, since the early 2000s, the trends are once again similar in both sides of the continent. They show an increase in persons convicted for drug offences, an increase in violent offences such as assault and robbery -which have probably reached their upper limit because the rates were stable from 2004 to 2006-, and a decrease of property offences. Only rape continued increasing slightly in Western Europe, but remained stable in Central and Eastern Europe since the mid 1990s.

As official statistics are influenced by the propensity of the population to report offences to the police, we have tested the hypothesis of an artificial increase of violent offences provoked by a reduced tolerance of violence in European societies that would lead citizens to report such offences more frequently. The empirical data did not corroborate that hypothesis. Reporting rates of assault and robberies remained stable in Western Europe from 1988 to 2004, and increased only slightly in Estonia and Poland.

We have also analysed the evolution of the composition of European prison populations and found that the majority of the persons currently held in penitentiary institutions are no longer serving sentences for property offences -as it was the case in the 1970s-, but for violent offences and drug offences. That finding provides additional empirical support to the trends in conviction statistics presented in this article. Moreover, as we have already mentioned, such trends are similar to the ones found in an analysis of police and victimization data for the same period. The only difference between conviction and police statistics concerned the evolution of intentional homicide, which showed a decrease according to police statistics, but a stable trend according to conviction statistics. This difference could be related to different factors, but an eventual increase in the proportion of domestic murders constitutes a hypothesis that deserves further investigation. Indeed, trends in domestic violence could have also played a role in the increase of persons convicted for assault, but currently there are no longitudinal data available to study that particular type of assault.

In sum, the trends in conviction statistics presented in this article corroborate that there is no general crime drop in Europe (Aebi and Linde 2010). They also corroborate that European crime trends do not follow a homogeneous direction. In particular, trends in homicide are not necessarily correlated with trends in property and other violent offences. As a consequence, the available explanations of the general crime drop in the United States cannot be applied to Europe, and the same is true for the explanations that could be drawn from most criminological theories. All of them suggest causes that have an influence on all types of offences, but are unable to justify how these causes would produce a decrease in property offences accompanied by an increase in violent offences and drug offences.

Only opportunity-based theories seem to provide a plausible explanation to these trends, especially when they take into account their historical, political and socio-economic context. In particular, the collapse of the Soviet Union facilitated transnational crime, increased the number of guns circulating in the continent, and weakened social control in Central and Eastern Europe where many countries also experienced a major increase in alcohol consumption and a clear deterioration of their health care system. As a consequence, the rate of persons convicted for all sorts of offences increased in both sides of the continent in the early 1990s. During that decade, the slow amelioration of the socioeconomic situation in Central and Eastern Europe was accompanied, in the whole continent, by an important rise of private security, formal social control, and security measures in households and stores. These developments reduced the number of 
opportunities to commit crimes and seem responsible for the following decrease of the rate of persons convicted for property offences and the stabilization of the rate of those convicted for homicide. Drug trafficking became thus the main way of obtaining quickly an illegal income. At the time, since the 1990s, there have been major changes in youth lifestyle provoked mainly by the development of the Internet and the growth of drug use and binge drinking. Youths who have unlimited access to the Internet spend more time at home - and are more exposed to the risk of engaging in computer related offences-, while those who have a limited access to the Web spend more time in the streets and are differentially exposed to the risk of engaging in conventional delinquency. Among the latter, there is an overrepresentation of youths with a low socioeconomic status and, particularly in Western Europe, many of the youths with such status are second-generation ethnic minorities. The number of the latter has clearly increased during the last decades, and research suggests that their presence is associated with the recent development of European street gangs, which are often involved in drug trafficking and group fighting. All these changes in youth lifestyle seem to be the main cause of the increase of persons convicted for violent and drug related offences in Europe.

\section{References}

Aebi, M. F. (2004a). Crime trends in Western Europe from 1990 to 2000. European Journal on Criminal Policy and Research, 10(2-3), 163-186.

Aebi, M. F. (2004b). Crime trends in Europe from 1990 to 2000. In: K. Aromaa and S. Nevala (Eds.). Crime and crime control in an integrating Europe: Plenary presentations held at the Third Annual Conference of the European Society of Criminology, Helsinki 2003 (pp. 39-60). Helsinki: HEUNI. Available online at (last accessed on 23-09-2011): http://www.heuni.fi/Etusivu/Publications/HEUNIreports/1198085296887.

Aebi, M. F. (2006). Comment mesurer la délinquance? Paris: Armand Colin.

Aebi, M. F. (2010). Methodological issues in the comparison of police-recorded crime rates. In S. G. Shoham, P. Knepper, \& M. Kett (Eds.), International handbook of criminology (pp. 211-227). Boca Raton: CRC Press.

Aebi, M. F., \& Delgrande, N. (2011). Council of Europe annual penal statistics - SPACE I: Survey 2009. Strasbourg: Council of Europe.

Aebi, M. F., \& Linde, A. (2010). Is there a crime drop in Western Europe? European Journal on Criminal Policy and Research, 16(4), 251-277.

Aebi, M. F., \& Linde, A. (in press). Regional variation in Europe between homicide and other forms of external death and criminal offences (1970-2008). In M. C. A. Liem \& W. A. Pridemore (Eds.), Handbook of European homicide research: Patterns, explanations, and country studies (pp. 71-94). New York: Springer.

Aebi, M. F., et al. (2006). European Sourcebook of crime and criminal justice statistics - 2006. 3rd edition. Den Haag: Boom Juridische Uitgevers. Available online at (last accessed on 23-09-2011): http://www. europeansourcebook.org/esb3 Full.pdf.

Aebi, M. F., et al. (2010). European Sourcebook of crime and criminal justice statistics - 2010. 4th edition. Den Haag: Boom Juridische Uitgevers. Available online at (last accessed on 23-09-2011): http://english. wodc.nl/onderzoeksdatabase/european-sourcebook-4e-editie.aspx.

Beirne, P. (1993). Inventing criminology: Essays on the rise of "homo criminalis". Albany: State University of New York Press.

Blumstein, A., \& Rosenfeld, R. (1998). Explaining recent trends in U.S. homicide rates. The Journal of Criminal Law and Criminology, 88(4), 1175-1216.

Blumstein, A., \& Wallman, J. (2000). The crime drop in America. Cambridge: Cambridge University Press.

Blumstein, A., \& Wallman, J. (2006). The crime drop in America. Revised edition. Cambridge: Cambridge University Press.

Blumstein, A., Tonry, M. \& Van Ness, A. (2005). Cross-National measures of punitiveness. Crime and Justice, 33 (Crime and Punishment in Western Countries, 1980-1999), pp. 347-376.

Bomio, G., \& Robert, C. N. (1987). Alphonse de Candolle, ou pourquoi lire un botaniste égaré dans la statistique judiciaire au début du XIXe siècle. Déviance et Société, 11(4), 337-363. 
Chamlin, M. B., \& Cochran, J. K. (2007). An evaluation of the assumptions that underlie institutional anomie theory. Theoretical Criminology, 11(1), 39-61.

Christiansen, K. O., \& Gram Jensen, S. (1972). Crime in Denmark - A statistical history. Journal of Criminal Law, Criminology and Police Science, 63(1), 82-92.

$\mathrm{CoE}$ - Council of Europe. (1999). European sourcebook of crime and criminal justice statistics. Strasbourg: Council of Europe. Strasbourg: Council of Europe. Available online at (last accessed on 23-09-2011): http://www.europeansourcebook.org/sourcebook_start.htm.

Cohen, L. E., \& Felson, M. (1979). Social change and crime rate trends: A routine activity approach. American Sociological Review, 44(4), 588-608.

Coleman, C., \& Moynihan, J. (1996). Understanding crime data: Haunted by the dark figure. Buckingham : Open University Press.

de Candolle, A. (1987a). Considérations sur la statistique des délits. Déviance et Société, 11(4), 352-355. reprinted from Bibliothèque Universelle (pp. 159-186), 1830, Genève / Paris.

de Candolle, A. (1987b). De la statistique criminelle. Déviance et Société, 11(4), 356-363. reprinted from Bibliothèque Universelle (23-59), 1832, Genève / Paris.

de Waard, J. (1999). The private security industry in international perspective. European Journal on Criminal Policy and Research, 7(2), 143-174.

Dodge, Y. (1993). Statistique: Dictionnaire encyclopédique. Paris: Dunod.

Donohue, J. J., III, \& Levitt, S. D. (2001). The impact of legalized abortion on crime. Quarterly Journal of Economics, 116(2), 379-420.

Dooley, E. (2001). Homicide in Ireland 1992-1996. Dublin: The Stationery Office. Available online at (last accessed on 23-09-2011): http://www.justice.ie/ga/JELR/DooleyE.Homicide\%20inIreland1992-1996. pdf/Files/DooleyE.Homicide\%20inIreland1992-1996.pdf.

Elsner, B., Smit, P. \& Zila, Josef (2008). Police case-ending possibilities within criminal investigations. European Journal on Criminal Policy and Research, 14(2-3), 191-201.

EMCDDA - European Monitoring Centre for Drugs and Drug Addiction. (2008). Annual report 2008: The state of the drugs problem in Europe. Lisbon: EMCDDA.

Emsley, C. (2005). Crime and society in England, 1750-1900 (3rd ed.). Harlow: Pearson Education Limited.

Eurostat. (2011). Unemployment statistics. Available online at (last accessed on 23-09-2011): http://epp. eurostat.ec.europa.eu/statistics_explained/index.php/Unemployment_statistics.

Farrell, G., Tseloni, A., Mailley, J., \& Tilley, N. (2011). The crime drop and the security hypothesis. Journal of Research in Crime and Delinquency, 48(2), 147-175.

Felson, M., \& Boba, R. (2010). Crime and everyday life (4th ed.). Los Angeles: Sage.

Ferracuti, F., Pérez-Hernández, R., \& Wolfgang, M. E. (1962). A study of police errors in crime classification. The Journal of Criminal Law, Criminology, and Police Science, 53(1), 113-119.

Garland, D. (1996). The limits of the sovereign state: Strategies of crime control in contemporary society. The British Journal of Criminology.

Garland, D. (2001). The culture of control. Crime and social order in contemporary society. Oxford: Oxford University Press.

Geneva Declaration Secretariat. (2008). Global burden of armed violence. Geneva: Geneva Declaration Secretariat.

Graham-Kevan, N. (2007). Domestic violence: Research and implications for batterer programmes in Europe. European Journal on Criminal Policy and Research, 13(3-4), 213-225.

Gruszczynska, B. (2004). Crime in Central and Eastern European countries in the enlarged Europe. European Journal on Criminal Policy and Research, 10(2-3), 123-136.

Harrington, V., \& Mayhew, P. (2001). Mobile phone theft. Home office research study no 235. London: Home Office.

Hastings, P. (2001). Crime and public order. In F. Lansberry (Ed.), Government and politics in Kent, 16401914 (pp. 210-248). Woodbridge/Kent: The Boydell Press/Kent County Council.

Hibell, B. et al. (2009). The 2007 ESPAD report: Substance use among students in 35 European countries. Stockholm: The Swedish Council for Information on Alcohol and other Drugs / The European Monitoring Centre for Drugs and Drug Addiction / Council of Europe, Co-operation Group to Combat Drug Abuse and Illicit Trafficking in Drugs.

IACP - The Committee on Uniform Crime Records of the International Association of Chiefs of Police (1929). Uniform Crime Reporting: A Complete Manual for Police. New York: J.J. Little and Ives.

Jarvis, C. (2000). The rise and fall of the pyramid schemes in Albania. IMF Staff Papers, 47(1), 1-29.

Jehle, J.-M., Smit, P., \& Zila, J. (2008). The public prosecutor as a key-player: Prosecutorial case-ending decisions. European Journal on Criminal Policy and Research, 14(2-3), 161-179.

Killias, M., \& Aebi, M. F. (2000). Crime trends in Europe from 1990 to 1996: How Europe illustrates the limits of the American experience. European Journal on Criminal Policy and Research, 8(1), 43-63. 
Killias, M., van Kesteren, J., \& Rindlisbacher, M. (2001). Guns, violent crime and suicide in 21 countries. Canadian Journal of Criminology, 43(4), 429-448.

Killias, M. et al. (2003). European sourcebook of crime and criminal justice statistics 2003. Den Haag: Boom Juridische uitgevers. Available online at (last accessed on 23-09-2011): http://www.minjust. nl:8080/b_organ/wodc/reports/ob212i.htm.

Killias, M., Aēbi, M. F., \& Kuhn, A. (2012). Précis de criminologie (3rd ed.). Berne: Staempfli.

Klein, M. W., Weerman, F. M., \& Thornberry, T. P. (2006). Street gang violence in Europe. European Journal of Criminology, 3(4), 413-437.

Koren, J. (1910). Statistics of crime. Journal of the American Institute of Criminal Law and Criminology, 1 (3), 417-437.

LaFree, G. (1999). Declining violent crime rates in the 1990s: Predicting crime booms and busts. Annual Review of Sociology, 25, 145-168.

Lamon, P. (2002). Crime trends in thirteen industrialized countries. In P. Nieuwbeerta (Ed.), Crime victimization in comparative perspective: Results from the international crime victims survey, 19892000 (pp. 29-52). The Hague: Boom Juridische Uitgevers.

Lenski, G. (1988). Rethinking macrosociological theory. American Sociological Review, 53(2), $163-171$.

Levitt, S. D. (1996). The effect of prison population size on crime rates: evidence from prison overcrowding litigation. Quarterly Journal of Economics, 111(2), 319-351.

Levitt, S. D. (2004). Understanding why crime fell in the 1990s: Four factors that explain the decline and six that do not. Journal of Economic Perspectives, 18(1), 163-190.

Lindström, D. (2008). Homicide in Scandinavia: Long-term trends and their interpretations. In S. BodyGendrot \& P. Spierenburg (Eds.), Violence in Europe: Historical and Contemporary Perspectives (pp. 251-274). New York: Springer.

Maguire, M. (2007). Crime data and statistics. In M. Maguire, R. Morgan, \& R. Reiner (Eds.), The Oxford Handbook of Criminology (pp. 241-301). Oxford: Oxford University Press.

Maltz, M. D. (1977). Crime statistics: A historical perspective. Crime and Delinquency, 23(1), 32-40.

Mucchielli, L. (2010). Are we living in a more violent society: A socio-historical analysis of interpersonal violence in France, 1970s-present. British Journal of Criminology, 50(5), 808-829.

Nectoux, M. (Ed.) (2010). Estimation of intimate partner violence related mortality in Europe: Synthesis of the scientific report. Paris: Société civile Psytel. Available online at (last accessed on 23-09-2011): http://www.psytel.eu/violences.php.

President's Commission on Law Enforcement and Administration of Justice. (1967). The challenge of crime in a free society. Washington: United States Government Printing Office.

Pridemore, W. A. (2002). Vodka and violence: Alcohol consumption and homicide rates in Russia. American Journal of Public Health, 92(12), 1921-1930.

Quételet, A. (1831). Recherches sur le penchant au crime, aux différents âges. Bruxelles: Mémoire présenté à l'Académie royale des sciences.

Ribeaud, D., Killias, M., \& Aebi, M. F. (2004). Long-term effects of heroine prescription on patients' offending behaviour. In Council of Europe (Ed.), Crime policy in Europe: Good practices and promising examples (pp. 27-36). Strasbourg: Council of Europe Publishing.

Robinson, L. N. (1910). A plan for the reorganization of criminal statistics in the United States. Journal of the American Institute of Criminal Law and Criminology, 1(1), 44-49.

Robinson, L. N. (1911). History and organization of criminal statistics in the United States. Boston: Houghton Mifflin.

Robinson, L. N. (1912). The unit in criminal statistics. Journal of the American Institute of Criminal Law and Criminology, 3(2), 245-248.

Robinson, L. N. (1920). The improvement of criminal statistics in the United States. Quarterly Publications of the American Statistical Association, 17(130), 157-163.

Robinson, L. N. (1928). The need for adequate criminal statistics. Journal of the American Statistical Association, 23(161), 123-127.

Robinson, L. N. (1933). History of criminal statistics (1908-1933). The Journal of Criminal Law and Criminology, 24(1), 125-139.

Rosen, L. (1995). The creation of the uniform crime report: The role of social science. Social Science History, 19(2), 215-238.

Rosenfeld, R., \& Messner, S. F. (2009). The crime drop in comparative perspective: The impact of the economy and imprisonment on American and European burglary rates. The British Journal of Sociology, $60(3), 445-471$.

Sarma, K. V. S. (2001). Statistics made simple. New Delhi: Prentice Hall.

Schaeffer Conroy, M. (1990). Abuse of drugs other than alcohol in the Soviet Union. Soviet Studies, 42(3), $447-480$. 
Sellin, T. (1931). The basis of a crime index. The Journal of Criminal Law and Criminology, 22(3), 335-356.

Sellin, T., \& Wolfgang, M. E. (1964). The measurement of delinquency. New York: Wiley.

Shelley, L. I. (2002). The challenge of crime and corruption. In S. K. Wegren (Ed.), Russia's policy challenges: Security, stability, and development (pp. 103-122). Armonk: M.E. Sharpe.

Stamatel, J. P. (2006). An overview of publicly available quantitative cross-national crime data. IASSIST Quarterly, 30, 16-20.

Taylor, I., Walton, P., \& Young, J. (1973). The new criminology: For a social theory of deviance. London: Routledge and Kegan Paul.

Tonry, M. (2010). Why are crime rates falling (or are they)? Criminology in Europe: Newsletter of the European Society of Criminology, 9(1), 3.

Tournier, P. V. (2011). Arithmétique pénitentiaire. Arpenter le Champ pénal, 9(Supplément d'été $\mathrm{N}^{\circ}$ 4), 2-8.

UNODC - United Nations Office on Drugs and Crime. (2010). United nations surveys on crime trends and the operations of criminal justice systems. Vienna: United Nations. Available online at (last accessed on 23-09-2011): http://www.unodc.org/unodc/en/data-and-analysis/United-Nations-Surveys-on-CrimeTrends-and-the-Operations-of-Criminal-Justice-Systems.html.

van Dijk, J. J. M. (1991). More than a matter of security: Trends in crime prevention-in Europe. In F. Heidensohn \& M. Farrell (Eds.), Crime in Europe (pp. 27-42). London: Routledge.

van Dijk, J. J. M. (1994). Understanding crime rates: On the interactions between rational choices of victims and offenders. British Journal of Criminology, 34(2), 105-121.

Van Dijk, J. J. M. (2006a). International comparisons of crime: The ICVS and more. Paper presented at the British Crime Survey 25th Anniversary Conference at Cumberland Lodge, England, 16-17 October, 2006.

van Dijk, J. J. M. (2006b). What goes up, comes down: Explaining the falling crime rates. Criminology in Europe: Newsletter of the European Society of Criminology, 5(3), 3, 17-18.

van Dijk, J. J. M. (2008). The world of crime: Breaking the silence on problems of security, justice, and development across the world. Los Angeles: Sage.

van Dijk, J. J. M. (2010). The European crime falls: Security driven? Criminology in Europe: Newsletter of the European Society of Criminology, 9(1), 5, 12-13.

van Dijk, J. J. M., van Kesteren, J., \& Smit, P. (2007). Criminal victimization in international perspective: Key findings from the 2004-2005 ICVS and EU ICS. Den Haag: Boom Juridische Uitgevers.

Von Hofer, H. (1990). Homicide in Swedish statistics, 1750-1988. In A. Snare (Ed.), Criminal violence in Scandinavia: Selected topics (pp. 28-45). Scandinavian studies in criminology (Vol. 11). Oslo: Norwegian University Press.

Von Hofer, H. (2000a). Crime statistics as constructs: The case of Swedish rape statistics. European Journal on Criminal Policy and Research, 8(1), 77-89.

Von Hofer, H. (2000b). Criminal violence and youth in Sweden: A long-term perspective. Journal of Scandinavian Studies in Criminology and Crime Prevention, 1(1), 56-72.

Von Hofer, H. (2003). Crime and punishment in Sweden: Historical criminal justice statistics 1750-2000. Journal of Scandinavian Studies in Criminology and Crime Prevention, 4(2), 165-167.

Weerman, F. M., \& Decker, S. (2005). European street gangs and troublesome youth groups: Findings from the Eurogang research program. In S. Decker \& F. M. Weerman (Eds.), European street gangs and troublesome youth groups (pp. 287-310). Lanham: Altamira.

WHO - World Health Organization. (2010). Health for all database (HfA). Technical notes. [Geneva: World Health Organization]. Available online at (last accessed on 23-09-2011): http://www.euro.who.int/en/ what-we-do/data-and-evidence/databases.

Wittebrood, K., \& Junger, M. (2002). Trends in violent crime: A comparison between police statistics and victimization surveys. Social Indicators Research, 59(2), 153-173. 2002.

Zimring, F. E. (2007). The great American crime decline. Oxford: Oxford University Press. 